Historic, Archive Document

Do not assume content reflects current scientific knowledge, policies, or practices. 



\section{You Can Now}

\section{SA VE MONEY}

\section{And Still Gel}

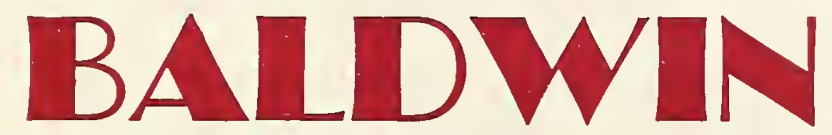

Qualíty

Nursery Stock

\section{A. D. BALDWIN NURSERY CO. \\ BRIDGMAN • : • MICHIGAN}

Postmaster-Forwarding and Return Postage Guaranteed.

If forwarded to a new address, notify sender on form 3547 .

Postage for notice guaranteed.
SEC. $435^{\frac{1}{2}}$, P. L. \& R.

U. S. POSTAGE

Paid

Bridgman, Mich. Permit No. 1

\section{LIBRAFY BEECHETVFID \\ - MAY 21930 Ł

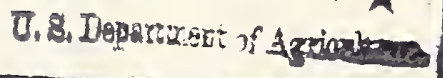





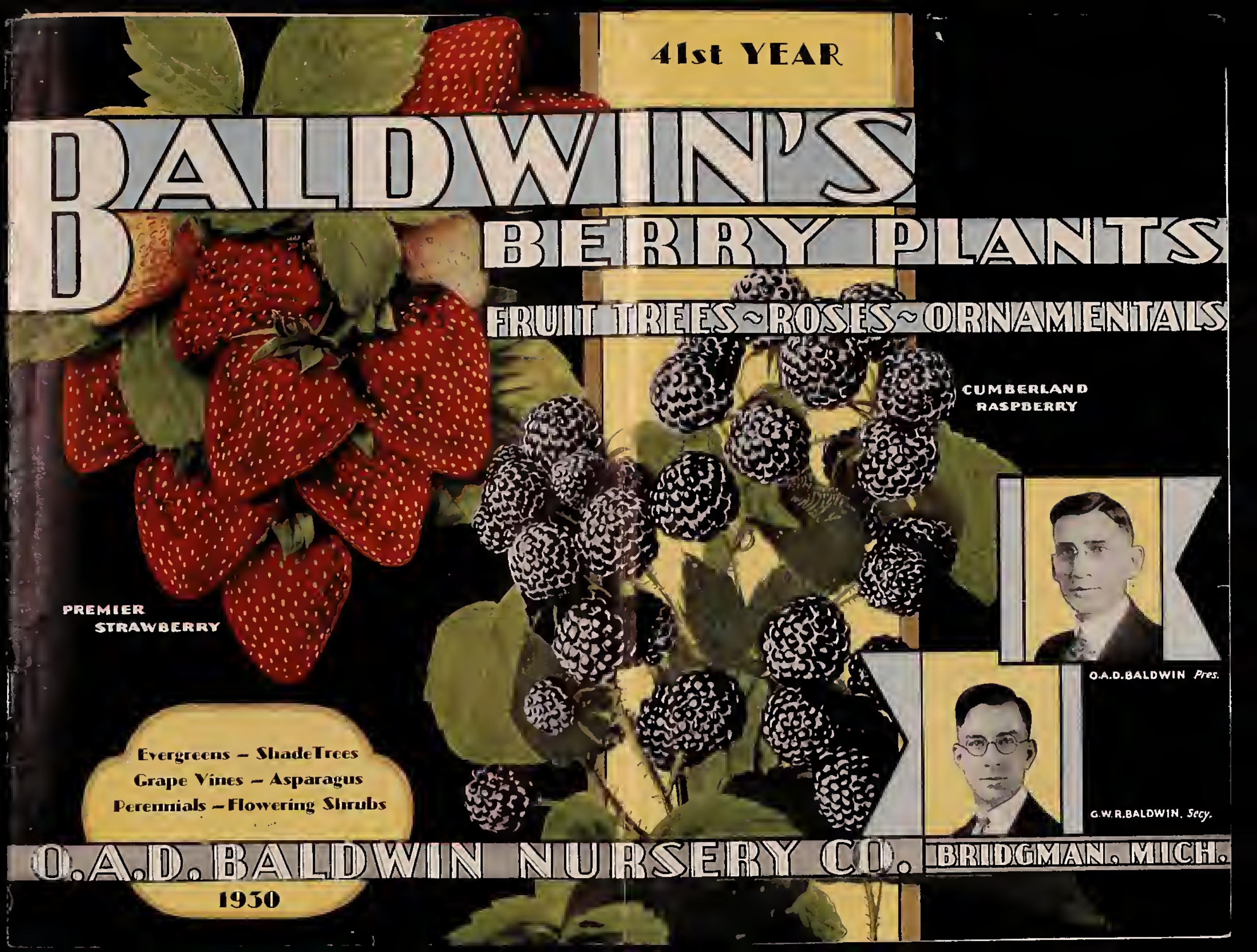




\section{A Sure Winner}

Wh e r e the finest strawber$r$ ies i $n$ the world have been grown for the past 18 years.

\section{GIBSON}

\section{Michigan's Greatest Berry}

That fact alone speaks volumes for its all around excellence. There is no question about its being one of the most profitable strawberries grown. A strong pollenizer and vigorous plant maker; thrives in all soils and climates. 2 to 4 large fruit stems on every plant loaded with great, handsome, glossy red berries.

Gibson possesses an exceptionally fine flavor. The ideal berry for table, market or can ning. Its good a p e a r a $n$ ce Price $\$$ Q 0 Per 4.50 Poro

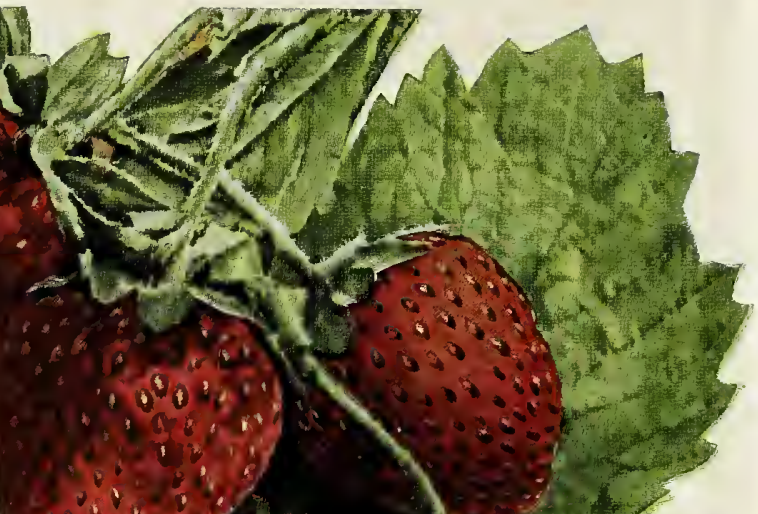
always sells it.

[Everbearing

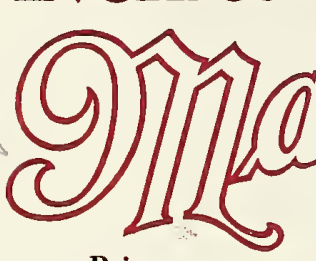

Price

$\$ 2.75$ Per 100

17.50 Per 1000

that it will do all we and many others claim for it. We would not be widely advertising and recommending it for general planting everywhere, if we did not believe in MASTODON. We know that this is by far the best everbearer grown-with a mishty goma sinrim loaring berry thrown in for good measure-and brings big profits to those who grow it.

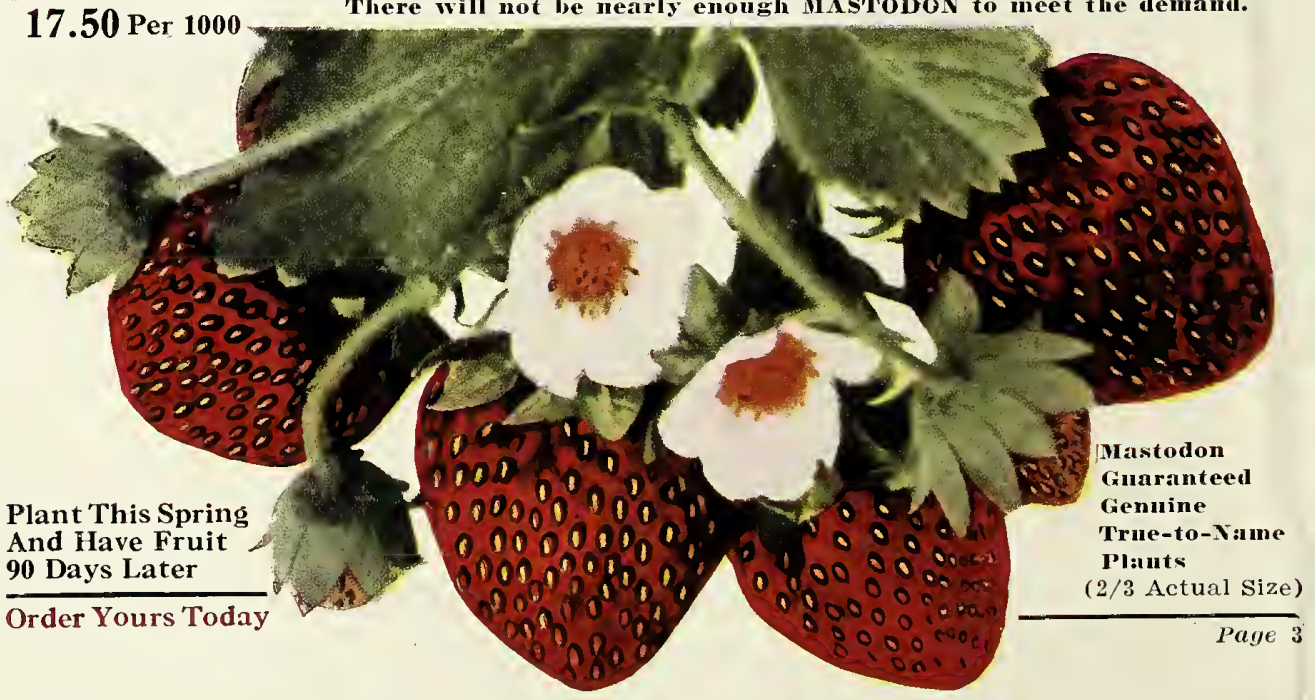




\section{Concord}

Grapes

The old reliable Concord - the standard by which all ot he r black grapes a $\mathrm{r}$ e judged - a lifet ime money maker! No vi n e$y$ a $\mathrm{d}$ or arbor is complete without Concord.

Note These Facts -

Concord produces big crops on any soil every year. After the first expense the cost of upkeep is but little. It is a profitable, permanent investment. Growers regularly make $\$ 500$ and more NET PROEIT per acre-you can do the same.

\section{Vines Scientifically Grown}

Our scientific methods are recognized by horticulturists as producing vines fully up to the standard of those grown in the east. They are even better adapted to the central west.

Our Concord vines are well rooted, and guaranteed to give perfect satisfaction. Best for market, eating and all home uses.

\section{Prices}

2-Year Medium-65̃ for $12 ; \$ 3.65$ for $100 ; \$ 24.00$ for 1,000 .

2-Year Extra Large-\$1.20 for 12; $\$ 5.95$ for $100 ; \$ 39.00$ for 1,000 .
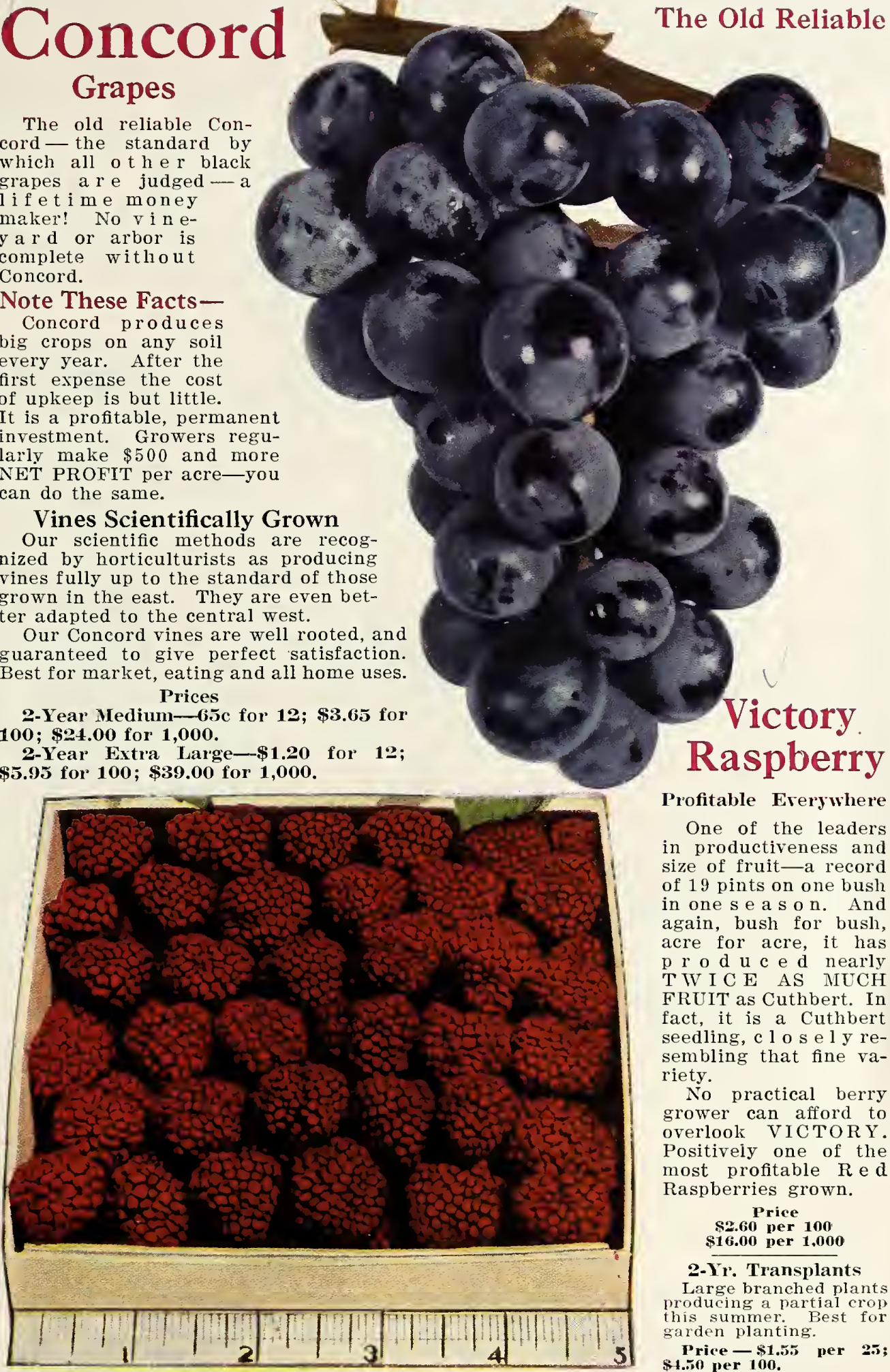

Profitable Ererywhere

One of the leaders in productiveness and size of fruit-a record of 19 pints on one bush in one s e a so n. And again, bush for bush, acre for acre, it has p r o d u c e d nearly TW I E AS MUCH FRUIT as Cuthbert. In fact, it is a Cuthbert seedling, c 1 o s e 1 y resembling that fine variety.

No practical berry grower can afford to overlook VICTORY. Positively one of the most profitable $\mathrm{R}$ e $\mathrm{d}$ Raspberries grown.

Price $\$ 2.60$ per 100 $\$ 16.00$ per 1.000

2-Ir. Transplants

Large branched plants producing a partial crop this summer. Best for garden planting.

Price-\$1.55 per 25; $\$ 1.50$ per 100. 


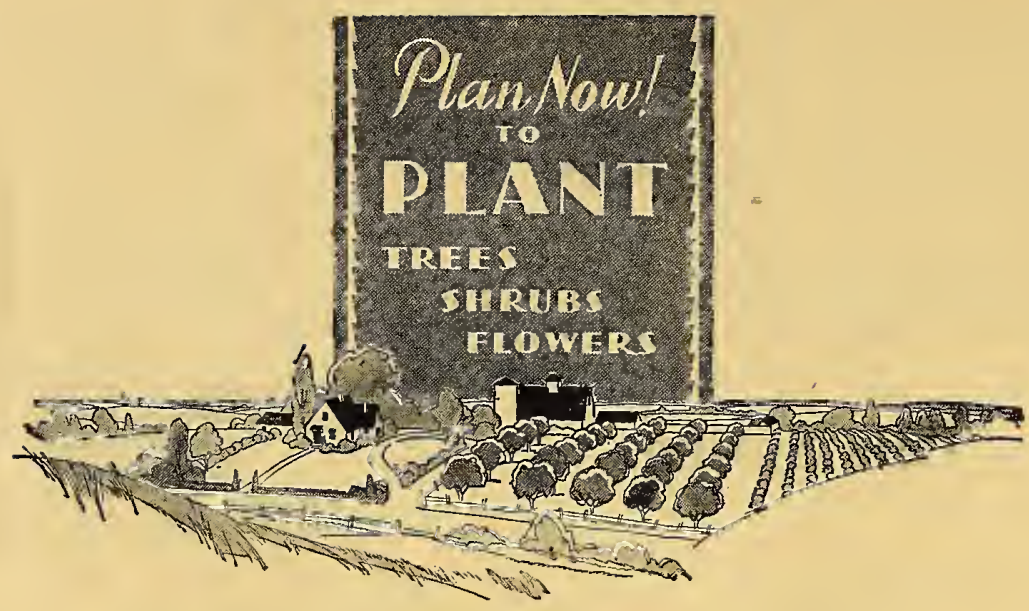

\section{Every Normal Human Being Wants - Health, Comfort, Profit -And This Means You!}

The home owners in this country of ours are becoming "Garden Conscious." It began last spring, increased during the summer and fall, until now you can't pick up a good magazine-such as Country Gentleman, Better Homes and Gardens, Ladies' Home Journal-without finding a timely article on planting fruits, flowers and shrubs about the home. To be in line with the times, every home must be well planted, attractive, beautiful. Incidentally, when you plant you add much to the value of your home.

We'll wager you can't look over the plants, trees, shrubs and flowers shown and described in this book without finding at least one that for some reason you would like to have. Look them over carefully now.

\section{This Book Offers You a More Complete Selection}

of

Fruits,

Flowers

Ornamentals and

Evergreens

Than Ever Before

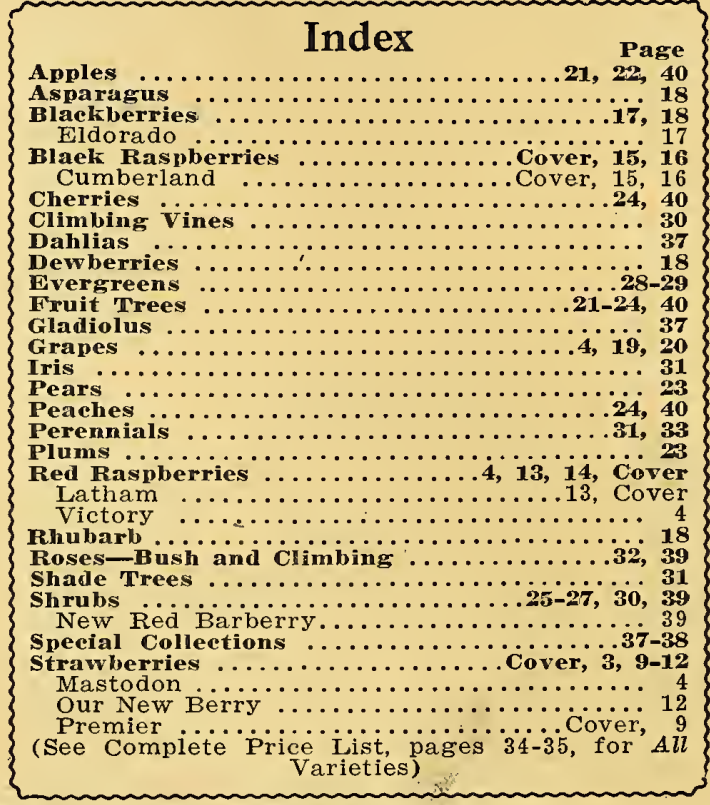

Save Money on Your Nursery Stock

New

Low Prices on All Quantities

Pages 34-35 



\section{Big Reasons Why}

\section{You Should Plant}

\section{Baldwin Stock}

\section{This Spring}

\section{Quality-}

First of all you want the best, whether you are buying a new hat or rose bush. Forty-one years constant experience has taught us how to grow the kind of nursery stock that will do what you have a right to expect. Don't be satisfied with any other.

\section{Service-}

Our long experience is at your command. We are ready to help you before you order with suggestions, whether you plan a commercial fruit farm, a home garden, a landscape planting, or a rose and perennial bed. When your order is shipped, it is filled with first quality stock and packed so that it will grow after you plant it. And afterward we want you to call on us with any growing problems you have.

\section{Price-}

You can pay a lot more than our prices for nursery stock, but why should you? You want the best but you don't want to pay more than a fair price for it. On the other hand, you know you can't afford to save a few cents on the first cost of stock and lose it many times over later. Our price policy over the years has been to sell as low as possible and still assure our customers the best in quality and service all the way through. Thousands of satisfied regular customers prove that this

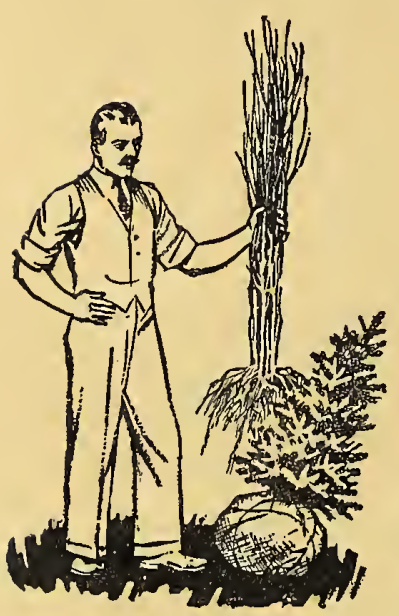

Plant Happiness is right.

\section{Look Thru Our Specially Priced Offers On Pages 37 and 38}

These are selected collections made up to make a complete planting easily planned

\section{"How to Plant the Home Grounds"}

\section{By E. H. WILSON}

Mr. Wilson is one of the foremost Horticulturists in the world, having been in charge of the famous Arnold Arboretum at Boston for many years. His clear, simple and helpful suggestions for planning and planting home surroundings are invaluable if you plan any kind of home planting. Well illustrated with photos and drawings.

We will mail this splendid booklet free to any one ordering $\$ 3.00$ or more; on smaller orders include $10 \mathrm{c}$ extra for it. If you want a copy of the booklet alone send $10 \mathrm{c}$ in stamps and we will mail it at once.

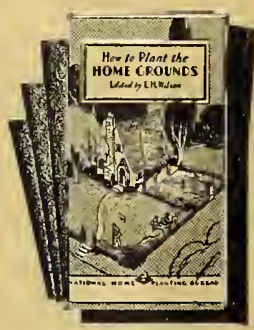




\section{Of Your Time?}

\section{If You are Like Most of Us You Want to Know the Folks with Whom You Do Business}

At the start, we are at a disadvantage trying to tell you about our plants, our way of doing business, and ourselves through the means of a catalog. We are common, everyday, friendly folks who take pride in what we have accomplished and what we are trying to do. We want you to know about it, too, because we believe we can be of real service to you in our line. If we could talk to you, or, better yet, if you

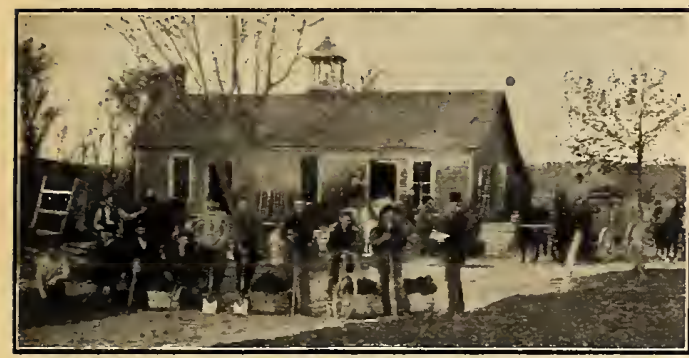

Ten Years Iater-1S99

could come and see us, our plant farms, packing houses and offices, we know we could show you why we are able to give the best there is in Fruit Plants, Fruit Trees, Shrubs, Flowers and Evergreens. And also, a full measure of individual service on every order large or small that means so much to you in making certain your success with nursery stock.

Back in 1889-41 years ago-the Baldwin nursery business was started. The pictures on this page show the strong,

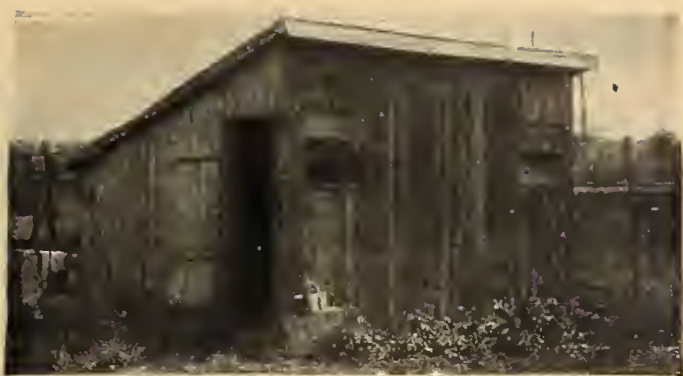

Our First Packing House-1Ss9

steady progress this business has made. Up-to-date propagating and packing methods always. We have learned a lot about growing nursery stock. Again this year, everything has been grown on specially selected, fertile soil-the right kind to produce as vigorous and healthy plants and trees as any you can buy.

\section{The Best Reference of Any Business Is a Long Record of Satisfied Customers}

This is a big business and we are justly proud of it-proud of our thousands of satisfied customers-good f $\mathrm{r}$ i e $\mathrm{n} \mathrm{d} \mathrm{s,} \mathrm{made}$ through 41 years of fair treatment and honest dealing. Don't think we are boasting at the other fellow's expense. We are tending strictly to our own business, a business we know from top to bottom. It is your business that makes ours grow; you are our partners, and we appreciate it. Ourselves and our business are at your service for your benefit.

$\left\{\begin{array}{c}\text { What One of Many Say } \\ \text { Stoyestown Pa., February 11, 1929. } \\ \text { Dear Sirs:- } \\ \text { Ten or fifteen years ago, I bought plants of } \\ \text { you by the thousands. At present I need only } \\ \text { a few for the garden. Alwoays found your } \\ \text { plants best that money could buy and always } \\ \text { recommended my friends to Baldwin. } \\ \text { Very truly yours, (Signed) P.P. Lanbert. }\end{array}\right.$

\section{Another Step Forward-}

See Page 12

Introducing "LATEBERRY"

Perfected Late Strawberry That a Million Growers Are Waiting For

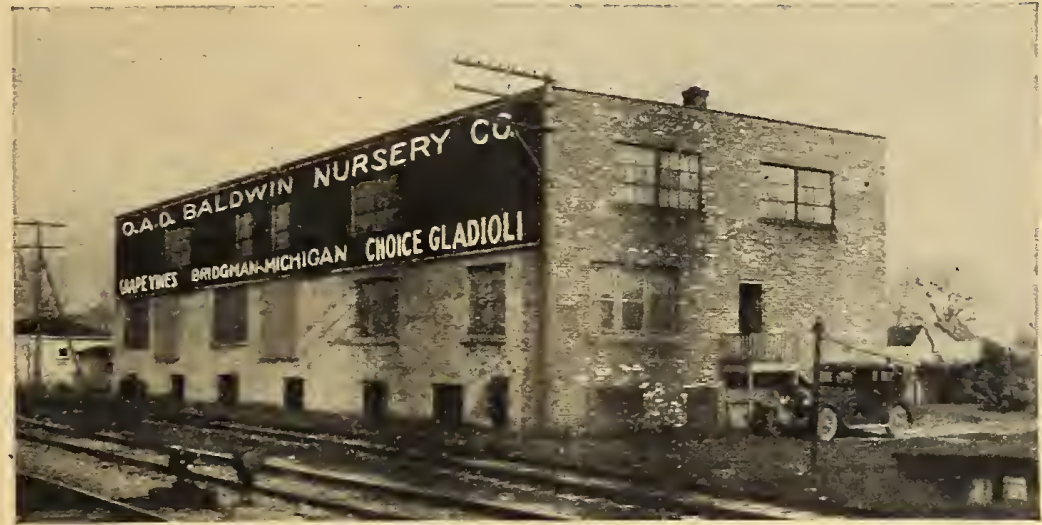

Today-1930-Modern Office and Packing Building Serves You Efficiently

"We Cannot Grow All the Nursery Stock In The World, So We Just Grow The Best Of It" $\quad$ Page 7 


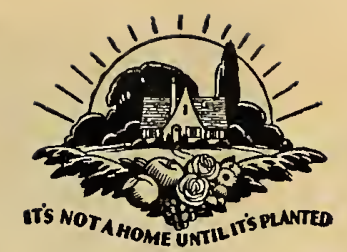

This seal means that we are one of several hundred modern progressive nurseries who are recognized as leaders in the business of growing and supplying you with the best of plants, trees and ornamentals and reliable planting and landscape information. You have seen this seal in advertisements, newspapers and garden club helps for the past year in the nation wide program to promote healthier, happier and more beautiful American Homes.

The appeal has "clicked" with the home owner everywhere. He did not know before how much needed to be done and how little it would cost to bring his place up to its best in beauty, profit and happiness.

Forty-one years ago this winter, O. A. E. Baldwin sent out a few hundred price sheets to fruit growers. That was the beginning of this business that we, his sons, are carrying on. His principles of always giving the best in quality, a full measure of service at an honest price, carried on year after year, have built this business to one of the largest and oldest, with thousands of satisfied customers throughout the country. It is our privilege to carry on with these high ideals guiding us day by day.-

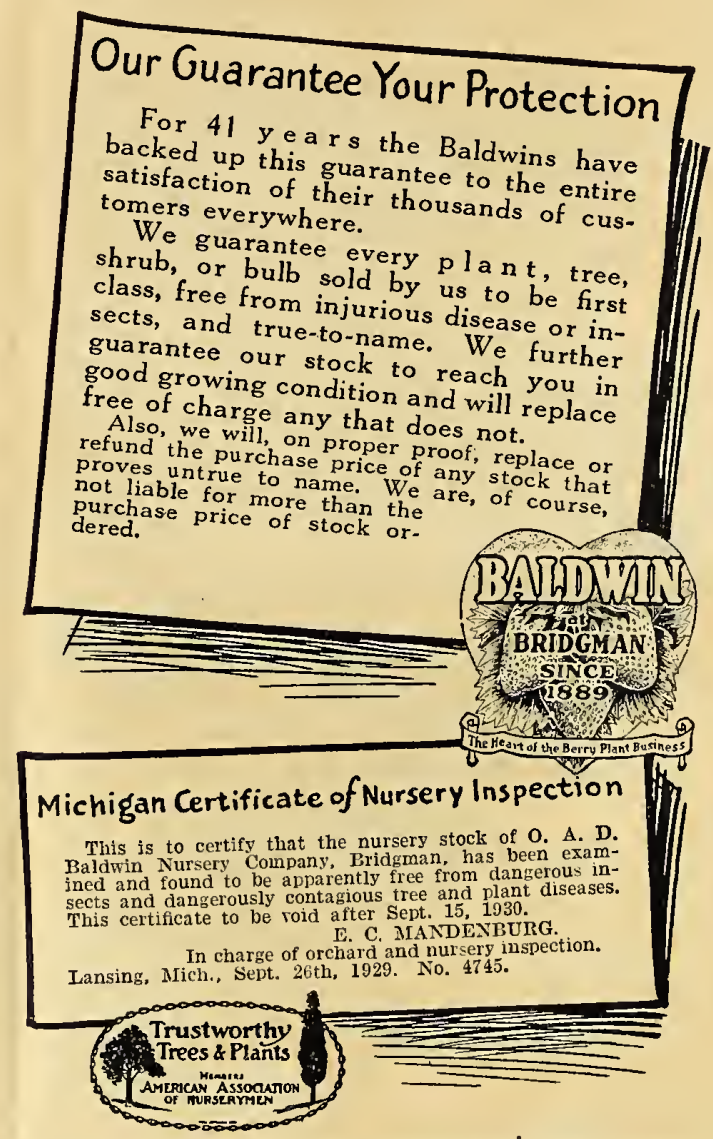

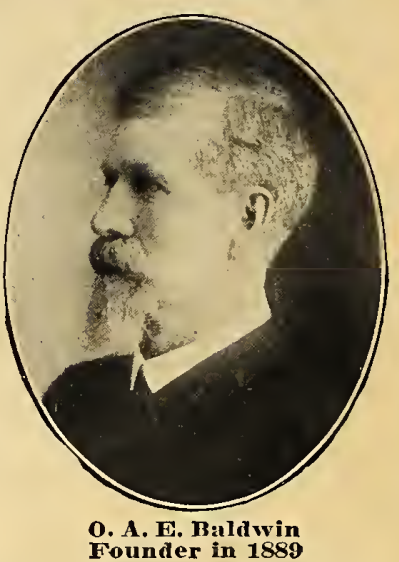

If you are planning on using nursery stock this spring-that is fine. You will be making a wise investment. If you are planning on using our stock, that is still better. But we don't want you to buy from us until you know something about us, our plants and our way of doing business. That is why we have tried to make this book the best one we have ever sent. We want you to read it over carefully. It will serve you as a guide, as well as a catalog of the best in nursery products.

The next sentence is particularly important, so read it over twice. This year it is more necessary than ever that you order early, because of the unusually dry growing season all through the country during last July, August and September. This means a scarcity of most everything.

As much as we would like to, we cannot meet all of our friends and customers personally, so we want you to consider this book our personal message to you. Write us, we would like to hear from you whenever we can be of service. If it is possible to visit us, do so, you will be welcome.

Faithfully yours, 



\title{
Sure-Yield Plants
}

\author{
Produce Such
}

Profit Making

Berries

\section{Again \\ Last Summer Strawberries Made Money}

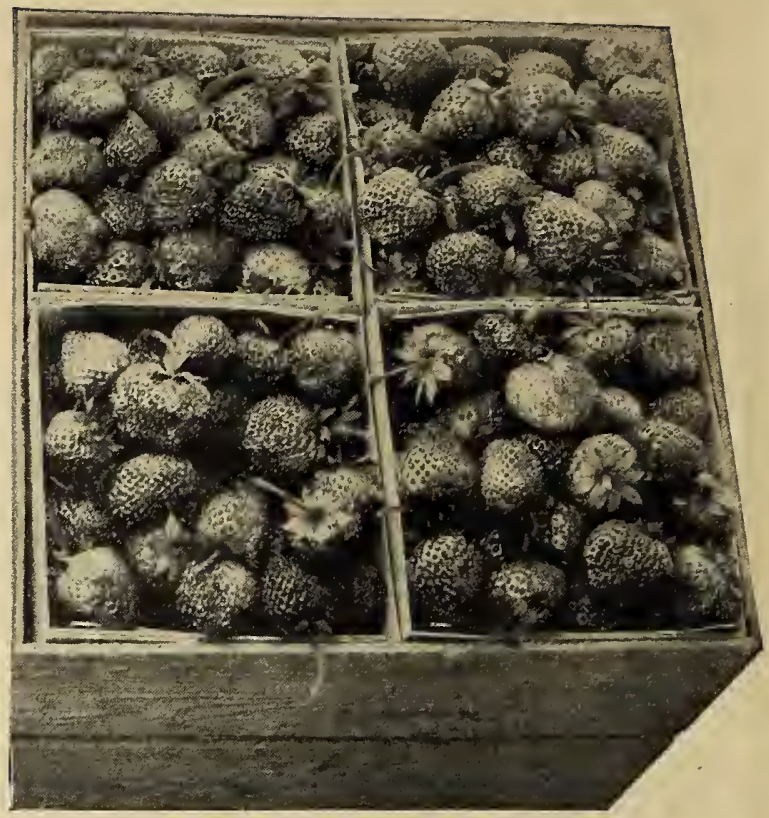

\section{They Do It Every Year-You Can Depend On Them}

Right now when all kinds of fruit are making money-strawberries are doubly profitable. 'They bring a full crop only one year from planting, are easy to grow on

any good soil, require no expert care and pay big returns on a small space of ground. They bear full crops for two seasonssometimes more. What more could you ask?

\section{Plant Proven Varieties Only}

Don't experiment with new untried sorts. Those we offer (only 9 out of many hundreds) have proven profitable in all fruit growing sections and what is more, our

plants are grown on ideal soils under scientific culture, so that you can be assured that Baldwin plants produce for you. Such certified plants cost you no more.

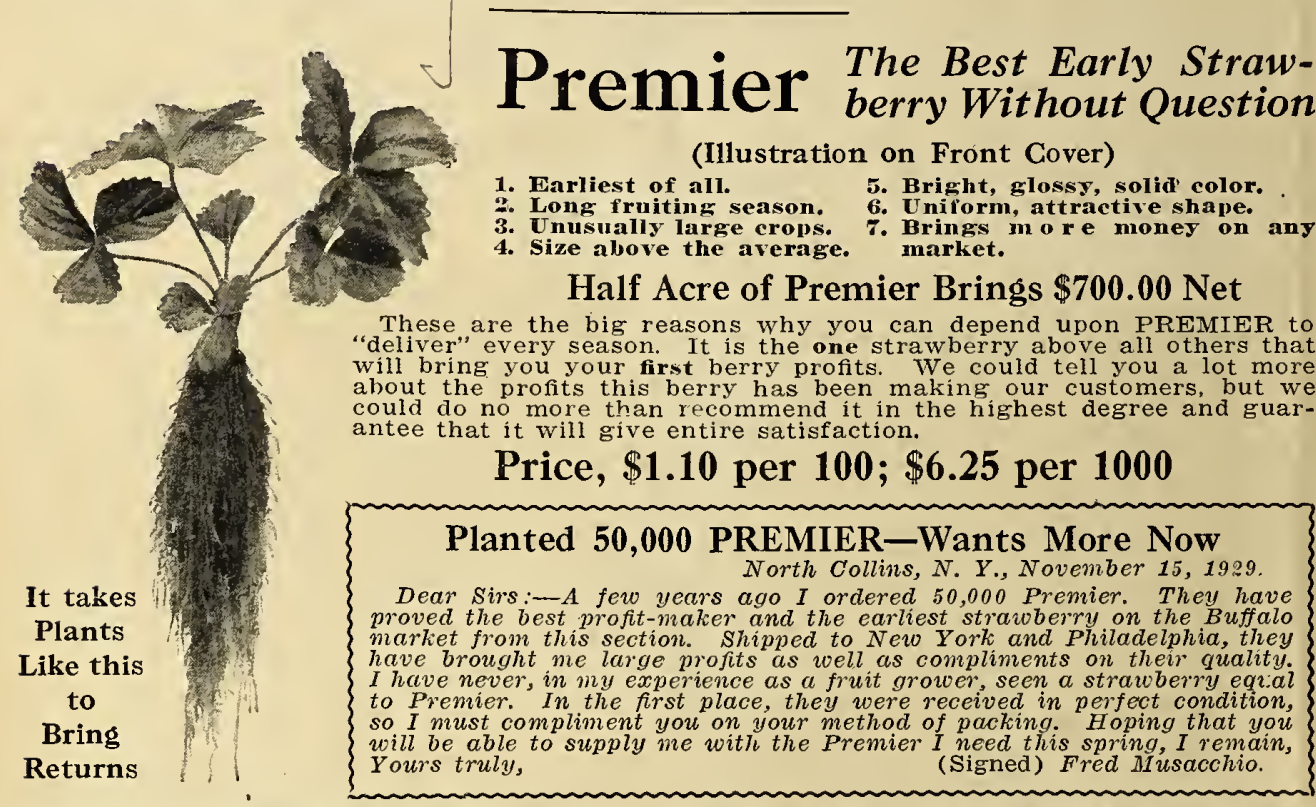

MASTODON-World's Best Everbearer-\&-GIBSON-Michigan's Biggest Acreage-Page 3 
Five Years'

Profitable Crops

Prove It a

Winner

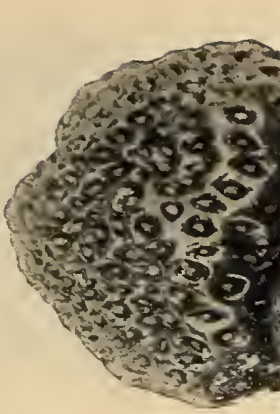

This is the berry for which we paid $\$ 250$ for a name. It is unusual in its many points of merit. The plant is large and vigorous leaves large, protecting the berry from the sun. The bloom is perfect. Berries are round, smooth and uniform, large in size and of brilliant crimson. The flavor is delicious. As a table delicacy it challenges all others. A very heavy producer-it is regarded as one of the best commercial strawberries.

\section{A Baldwin Introduction}

BOOSTER is one of the best mid-season strawberries the world has ever produced. There are other good strawberries listed in this book, but you should not fail to include BOOSTER plants when sending in your order.

We hope our stock is large enough to meet the heavy demand, but we advise you to get your order in early and make sure that you get some of these wonderful plants now.
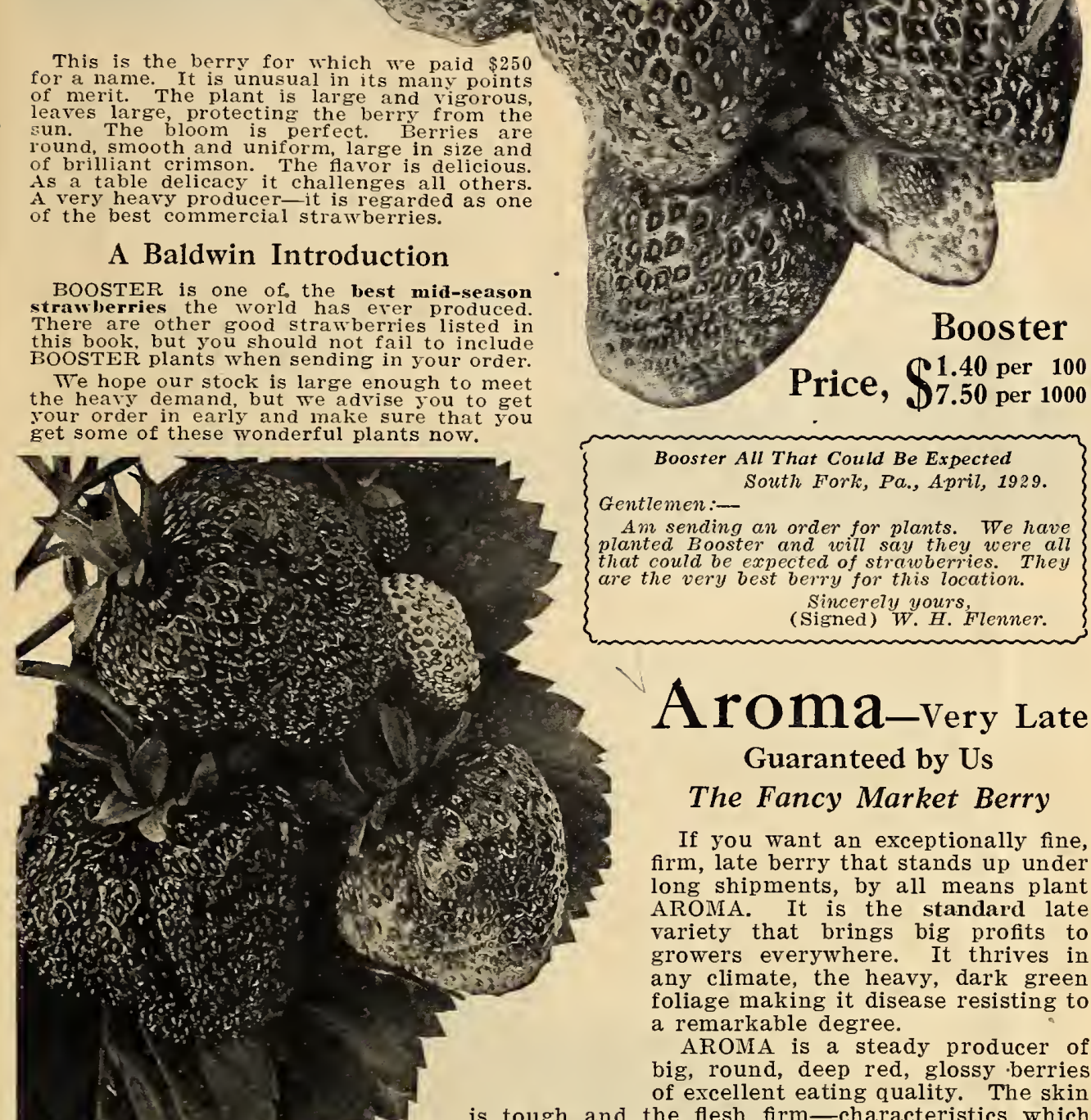

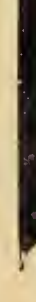
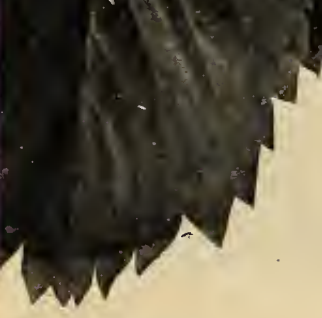

Booster All That Could Be Expected South Fork, Pa., April, 1929.

Am sending an order for plants. We have anted Booster and will say they were all that could be expected of strawberries. They
are the very best berry for this location.

Sincerely yours,

(Signed) W. H. Flenner.

\section{Aroma-very Late}

\section{Guaranteed by Us}

\section{The Fancy Market Berry}

If you want an exceptionally fine, firm, late berry that stands up under long shipments, by all means plant AROMA. It is the standard late variety that brings big profits to growers everywhere. It thrives in any climate, the heavy, dark green foliage making it disease resisting to a remarkable degree.

AROMA is a steady producer of big, round, deep red, glossy berries of excellent eating quality. The skin is tough and the flesh firm-characteristics which make it such a splendid shipper.

AROMA is unusually mild and sweet. It is a fancy berry in the truest sense of the word which greatly adds to its marketability at top prices. It has steadily been growing in favor for the last 13 years and has proved its worth under all conditions. Our guarantee is behind

this variety in every re- Price $\$ 0.95$ per 100 spect. 


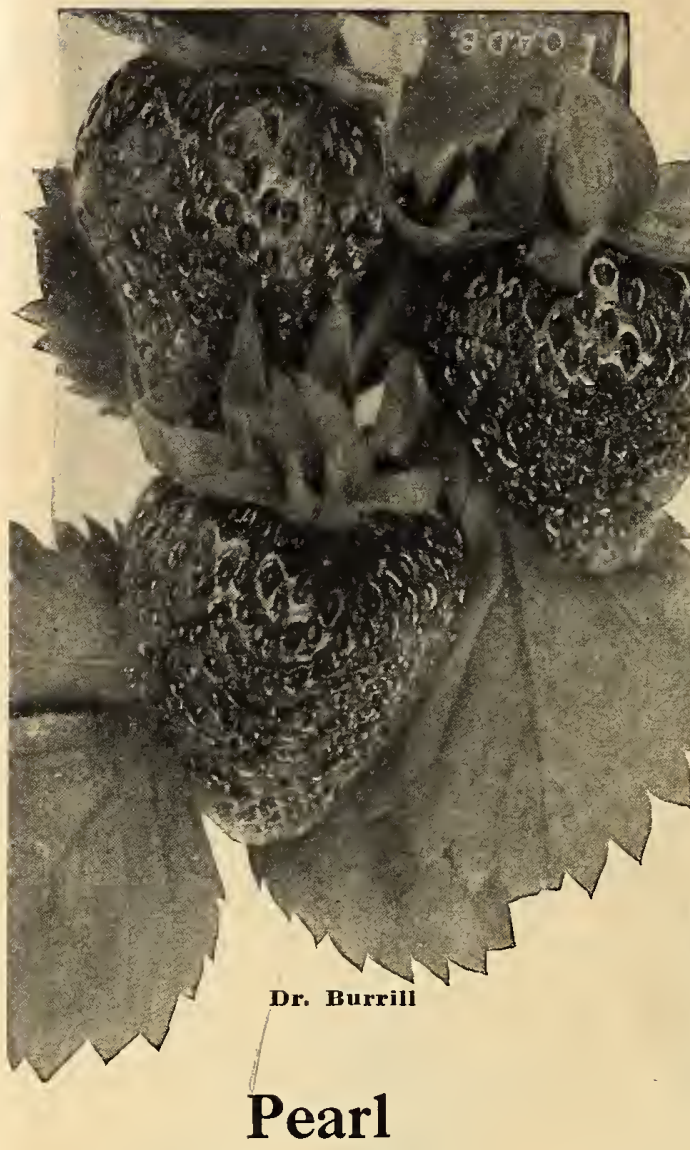

\section{Latest June Berry}

PEARL is the berry needed by strawberry growers-it insures a big, annual crop of fine berries at the end of the season.

\section{Late Grops Mean High Prices}

Blooms freely and opens its buds late enough in the spring generally to avoid late frosts. That's why its crops are so heavy and can be counted on so surely. Berries are very large, of dark red color. A fine shipper

In the North it does not come into its prime until late in June, when other varieties are off the market-always bringing top prices.

Price, $\$ 1.40$ per $100 ; \$ 7.50$ per 1000

\section{Dr. Burrill}

"The Million Dollar Berry"

Tells Its Success Story

Everywhere

Truly a most remarkable berry-one of the best all-around Strawberries ever produced It is really in a class by itself Commercial growers always feel safe in planting it-and sure of its ready sale at good prices. Home grower's have good success and find it so easy to raise.

\section{Fruits Mid-Season to Late}

A ready seller on the market. As a dry-weather producer it can't be beaten, the long roots taking moisture from a greater soil depth and producing heavier crops than most varieties under similar conditions.

Price, $90 \notin$ per $100 ; \$ 4.50$ per 1000

\section{Senator Dunlap}

\section{A "Best Seller"-For 25 Years}

Perhaps no other Strawberry is so well and favorably known throughout the country. It has the reputation of producing full crops in a wider range of soil and climate than any other variety. No wonder, then, that growers in nearly every state in the Union order more and more of this old reliable berry every year. Today Senator Dunlap is one of the three or four strawberries that are known and asked for by buyers throughout the country wherever strawberries are bought Everyone knows he can depend on unvarying high quality in this long-proven variety.

\section{Certain Profits-Medium Early}

That's what the practical grower wants. Big, uniform berries of dark red color. Splendid shipper and ready seller because of its attractive appearance.

Cauning factories want nothing but senator Dunlap. Local canneries make yearly contracts for thousands of cases, using no other kind. They know it always holds its shape and rich color long after canning-and that the flavor lasts.

Taliing all into consideration, here's a berry that will bring you results-a big profit on your investment-take our word for it.

Prices, $80 \notin$ per $100 ; \$ 4.00$ per 1000

\section{Big Cooper-Medium Early}

\section{Big in Berry-Big in Yield-Big in Profit}

Nine COOPERs make a layer in a full size quart box-27 fill the box! That gives you some idea of the size of this magnificent berry, and explains, too, why they sell for 10 to 12 cents more per quart than other fancy varieties. For profit on the roadside market there is no better seller than this mammoth berry.
Unlike many extra, large Strawberries, every COOPER is firm throughout, with no green tips. As for sugary sweetness and delicious flavor, COOPER simply can't be beaten. It is a heavy producer-big plants and thick fruit stems hold berries off the ground.

Price, $\$ 1.40$ Per $100 ; \$ 7.50$ Per 1000 


\section{Here It Is!}

\section{The Strawberry 1,000,000 Growers Want}

Baldwin's New Perfected

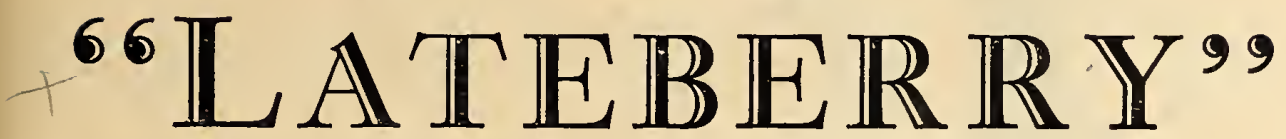

\section{Big Berry-Bears Heavily-Ripens Later-Greater Profits}

Every year for several years hundreds of strawberry growers have asked- "Can't you give us a better extra late berry-one as big as Aroma but a heavier bearer, and as late as Pearl but larger and of more attractive appearance? Such a berry would mean many more dollars profit in our pockets!"

LATEBERRY is a variety that fills this need for every berry grower. It is by far the best late strawberry we have ever testedand we have tried many. For 3 years we have grown it under all conditions, and it has made good in every respect.

"LATEBERRY" expresses in one word the outstanding features of this new variety. It is "The Berry" on every count of all late sorts. It is hard to make you realize just what a fine berry this is. We would not be recommending it and guaranteeing it fully as we are if we were not positive that it is every bit as good as we say it is. We have a real pleasure in offering this most excellent berry to fill the need so long felt by fruit growers in every section.

Plant this spring and see for yourself. Use 100 or 1,000 plants as you can. It will pay yon. The smpply is limited and we urge you to order now.

\section{Lateberry's Profit-Making Points}

1. Most important of all is its Late Season. This makes added profits-strawberries are scarce then.

2. Firmest berry we have ever seen. Think what this means in shipping and keeping qualities.

3. Beautiful appearance-bright red glossy tough skin and prominent yellow seeds topped by a brilliant green hull. After 36 hours these colors are still bright and attractive-_-a pleasant point in home use and actually means more dollars in market returns.

4. Wonderfully mild sweet flaror-no acidsour here.

5. Every berry well above average size. We don't claim it is the largest berry grown. But examine the photograph of the box of berries -an even run of such good sized berries of top quality and finest appearance is more desirable than a few extra large with many small ones.

6. Heavy regular bearer in all fruit locations. Most late kinds fall short here, but not "Lateberry." You can depend on it.

Special Introductory Prices

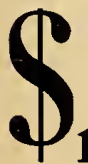

7. Blossoms are perfect. No other kind need be planted with Lateberry to produce a full crop. Blooms open late, avoiding spring frosts.

8. Desirable in garden or field. Its many outstanding good qualities make it equally desirable in the home garden or commercial field.

9. "Lateberry" has our fullest recommendation and endorsement for growth, crops, quality and satisfaction.

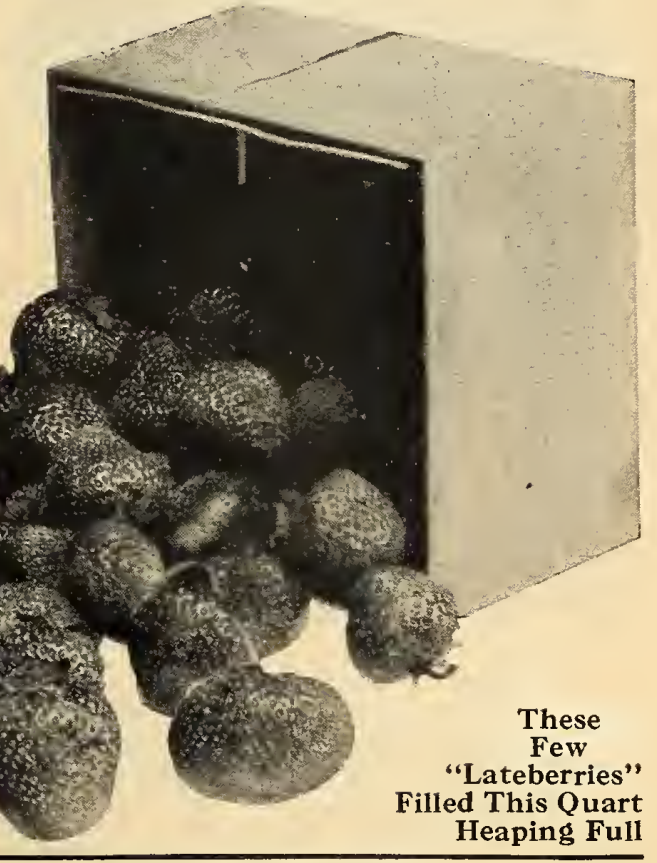




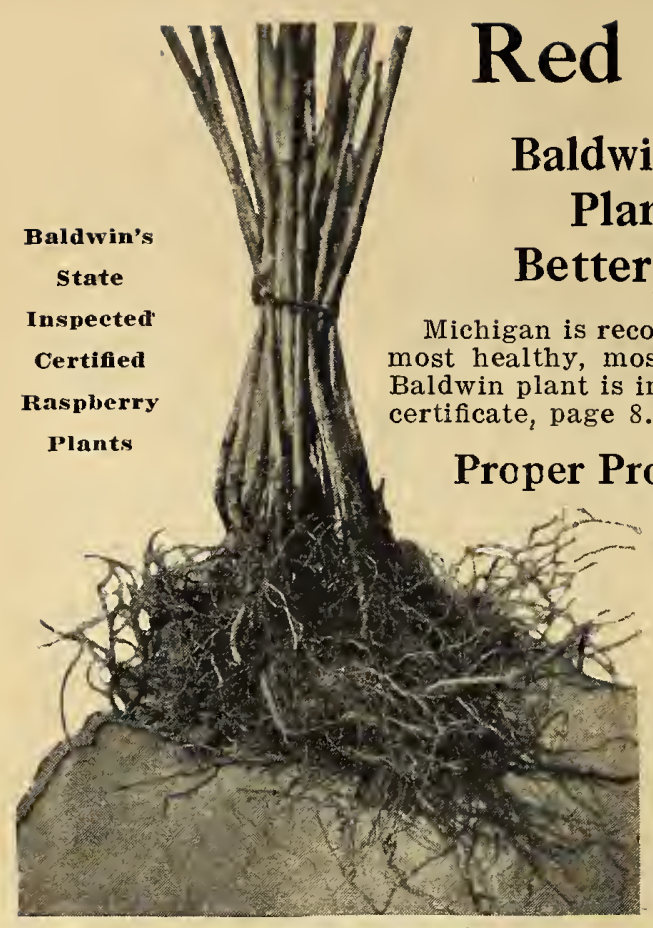

Cuthbert Prices

क. 2.25 per 100

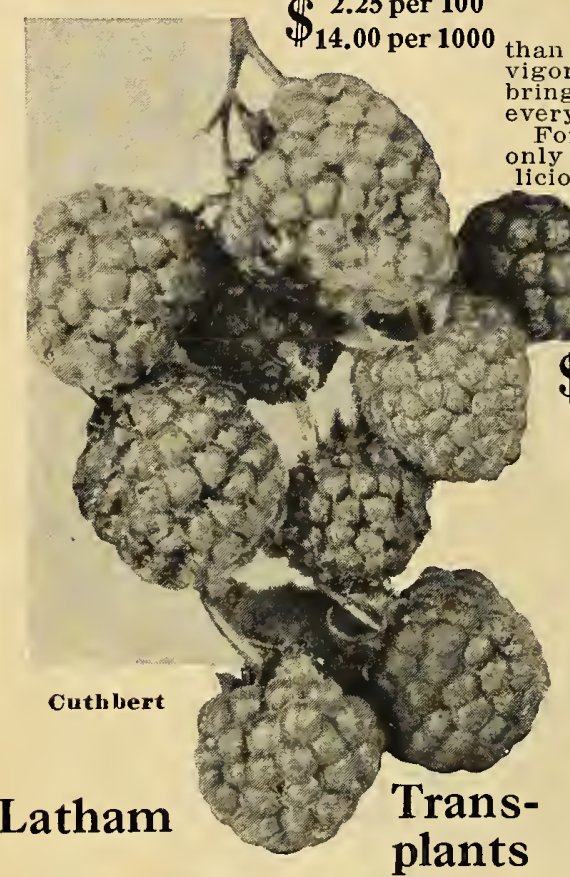

Fruit This Summer

Two year plants, large and we 11 branched, that will give you a partial crop this summer. Excellent for garden planting. Sure to grow-quick crops. Have only a few in stock, so don't delay. Price, \$2.40 per 25; \$6.85̃ per 100 . cious.

\section{Baldwin's Disease-Free, Vigorous Plants Bring Bigger Yields of Berries and Cost No More}

nized throughout the country as having the vigorous raspberry plants grown. Every See insp

\section{duction-Double Inspection}

\begin{abstract}
This means success or failure to the fruit grower because a plant "sick" with disease or poorly grown will never bear a full crop. Our propagating methods, improved and tested through long years of experience, make it certain you will get your full money's worth in
\end{abstract} Baldwin raspberry plants.

\section{Red Raspberries Continue Fruit Profits}

The right varieties of red raspberries continue paying crops after strawberries are gone. They keep the money rolling in. These varieties are the best, and our plants are rightplant this spring assured of successful crops.

\section{Cuthbert It Grows and Pays}

This variety is grown in larger quantities than perhaps any other red raspberry. Bushes are hardy, vigorous and productive. Season is late. Cuthbert always ings top prices and is the standard of good quality on ery market.

For canning, Cuthbert is hard to beat-Latham is its Holds its color and shape. The flavor is de-

\section{Save a Year with Transplants}

Big, well branched, two-year plants Price grown in the nursery row that will pro(1) 1.30 per 25 home garden or for a quick money re3.75 per 100 transplant commercial planting-use

\section{Latham ( $\left.\begin{array}{c}\text { See Illustration on } \\ \text { Back Cover }\end{array}\right)$}

\section{Best Late Raspberry}

When we say "Best" we mean just that. In 5 years LATHAM has become recognized by fruit growers as the most profitable late berry ever grown, and by fruit users as having the richest color and most delicious flavor imaginable. Hardy and very productive-far outyielding all others. Regularly brings more money on any market. We wish we could convince you what a truly fine berry LATHAM is in every way. The supply of plants is not large and we sincerely hope you will order now so we can reserve what you want.

For Canning-Jams and Jellies-Unusually rich color that does not fade, and what a wonderfully delicious, true, fresh raspberry flavor!

GOVERNMENT EXPERIMENT STATIONS report from leading fruit states that Latham is by far the best quality berry yet tested and is highly recommended for planting.

Baldwin's Guaranteed, Diseasefree, Genuine LATHAM - "The Kind It Pays to Plant." 24.00 per 1000 


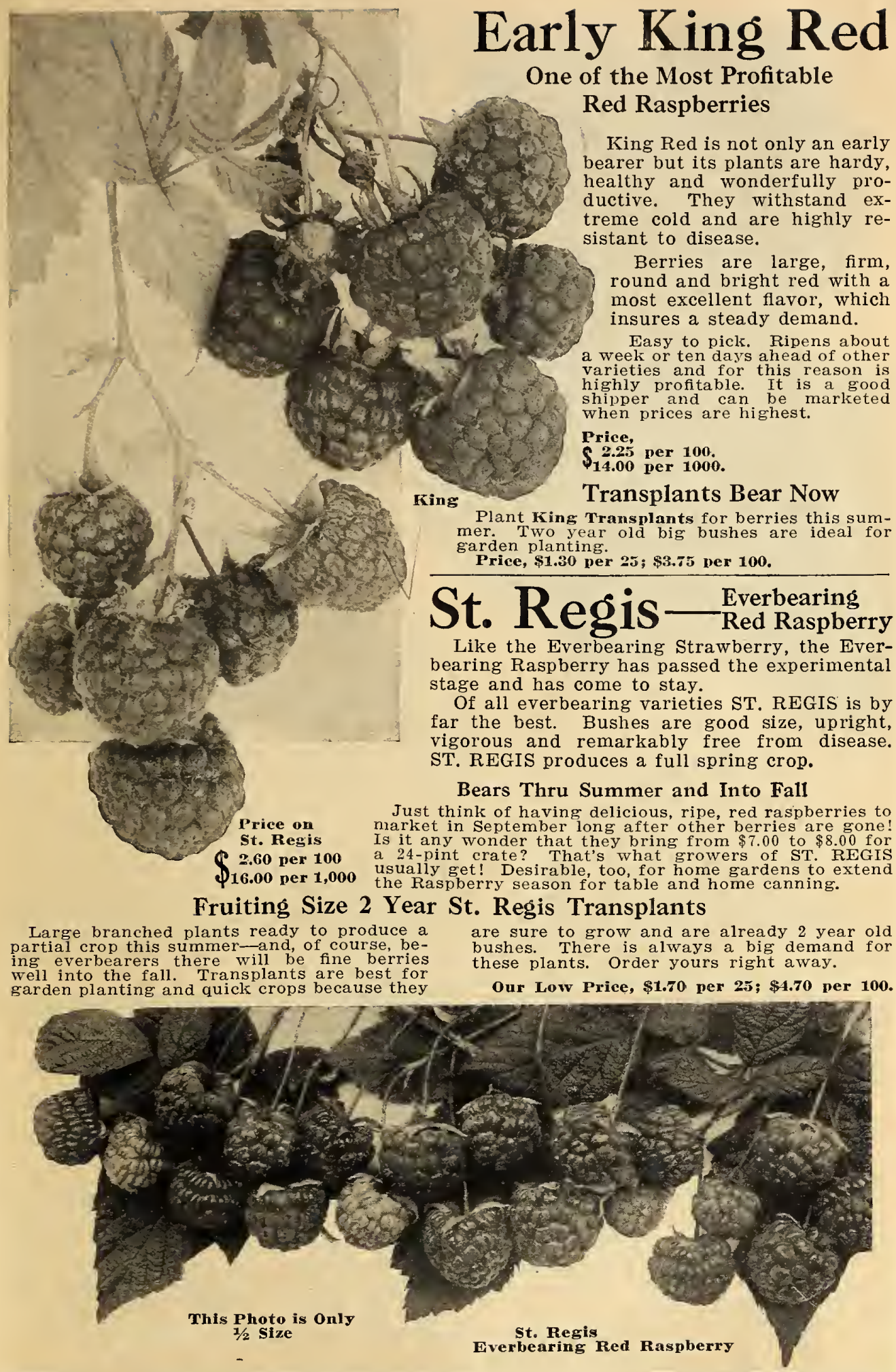




\section{Black Raspberries}

\section{Sure to Yield-Regular Profits}

Blackcaps are especially liked as a table and canning berry everywhere and for these reasons canneries are using more every year and paying good prices. You will be getting in line for good plofits by planting our Michigan grown, high producing plants this spring.

\section{Cumberland}

(See Color Illustration on Front Cover)

\section{Thrives Everywhere-Makes Money Always}

$\$ 200$ clear money per acre above all expense is what a local grower made on his 8 acre field of CUMBERLAND. You can do the same with Baldwin Quality Plants.

The Standard Black Raspberry everywhere. Plants vigorous and very productive; thrive everywhere. Berries large, firm, jet black with a delicious flavor. Wonderful long distance shippers -attractive appearance-always command good prices. We guarantee it to please you and make you big money.

Michigan grown, double-inspected Raspberry Plants are recognized throughout the country as the best. Our soil is especially adapted to produce sturdy, well rooted plants.

$$
\text { Price, } \begin{aligned}
2.95 & \text { per } 100 \\
18.00 & \text { per } 1000
\end{aligned}
$$

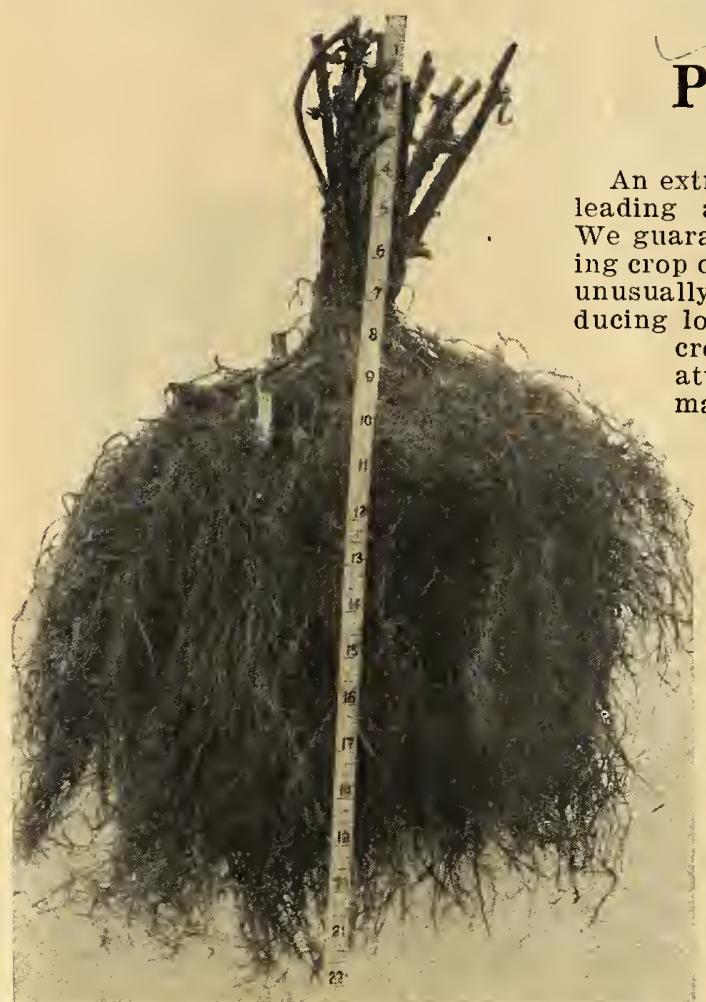

Plum Farmer

\section{Best Early Blackcap}

a early variety that has become one of the and most profitable Black Raspberries. arantee PLUM FARMER to bring you a payof extra fine fruit. Plants are very healthy, usually free from disease, strong growing, prots of bearing wood and insuring a heavy crop. The berry is grayish black, very firm, attractive and a good shipper. A favorite market variety with many, as practically the entire crop can be harvested in three pickings. PLUM FARMER is extra early and always brings top prices.

\section{Plum Farmer Prices, di 2.95 per 100 . $\$ 18.00$ per 1000 .}

\section{Why Baldwin Plants Pay- The Picture Tells The Story}

It's root growth that counts and our secret of producing it is first. a combination of soil and climate that is especially adapted to plant growth and second, proper propagation methods tested and proved by forty years of nursery experience. These two things, connected. with the fact that every plant grown and sold in this state is twice inspected by state inspectorsmaking Michiman Double Inspected raspberry plants the standard in all fruit sections-assures you of the very best stock money can buy. And we offer these plants to you at a reasonable price.

Such roots mean sure growth and full crops. 


\section{Cumberland Transplants}

\section{Year Plants Bring Quick Profits}

This year we have a limited supply of Cumberland Transplants-tip plants that have been transplanted and grown a year in our nurseries. Large bushy plants.

\section{Some Fruit This Summer Full Crop Next Year}

Each year there is an increasing demand for $\mathrm{Cum}$ be $\mathrm{rl}$ a n d Transplants. They are being planted in the home fruit garden, where they are especially satisfactory, because of their sure growth and early full bearing. They more than return the difference in cost over one year plants. To bring quick crops and quick returns, include some of these Transplants in your order. Don't wait too long. We have only a few and will be sold out early.

Price, \$1.95 per 25; \$6.00 per 100. Only 100 to each customer.

\section{Honeysweet Best for Home Use}

Introduced as an extra large, fancy berry of superior quality, it has proven its claims. HONEYSWEET is a distinct variety in every respect-in vigorous growth of plants-the large jet black berries without a trace of bloom-in the larger crops produced-and in its delicious, sugar sweet flavor.

\section{Worth the Cost in Any Garden}

If you are looking for an especially highclass variety, that will produce large, fancy berries, buy HONEYSWEET. It is true that the planting cost is a little greater than the other varieties, but we know you will feel well repaid with HONEYSWEET.

Price $\quad \$ 25.75$ per 100

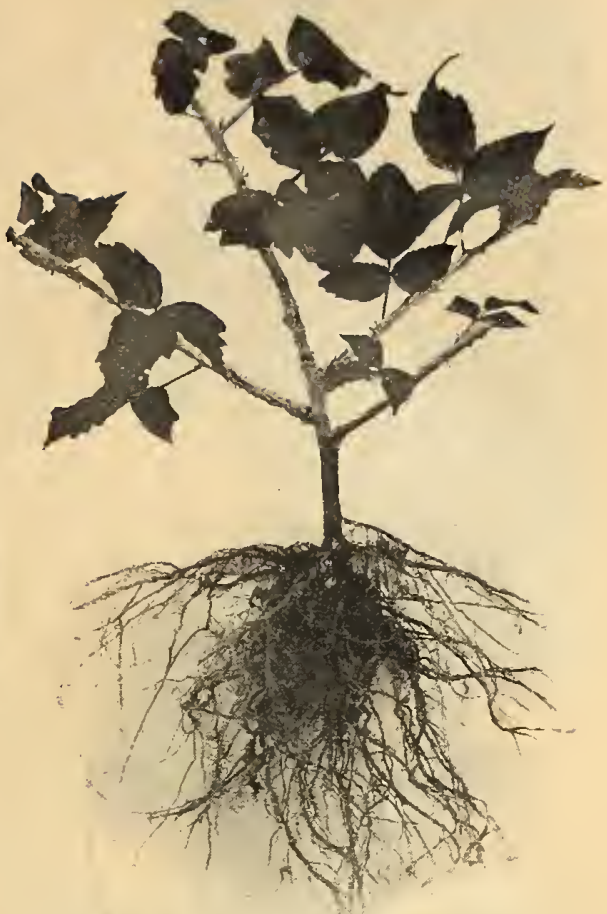

Sturdy Cumberland Transplant

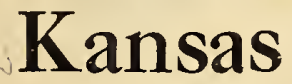

\section{A Good Variety}

Preferred By Many. Now a general favorite Black Raspberry all over the country. Ripens early, jet black, firm, of the best quality; a strong grower, stands drought and cold. Very productive. A money maker.

Price, \$2.95 per $100 ; \$ 18.00$ per 1000 .

$\left\{\begin{array}{r}\text { Best Plants He Fver Bought } \\ \text { Jerry City, Ohio, April 8, 1929. } \\ \text { Gentlemen -Wish to acknowledge receipt } \\ \text { of the rasperry plants. They arrived in } \\ \text { splendid condition, and were, I believe, the } \\ \text { best plants we have ever bought. Judging } \\ \text { from the plants, you know how to grow them } \\ \text { and any help you may give will be greatly } \\ \text { appreciated. Yours truly, }\end{array}\right.$

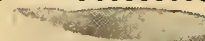

\footnotetext{
triste
}

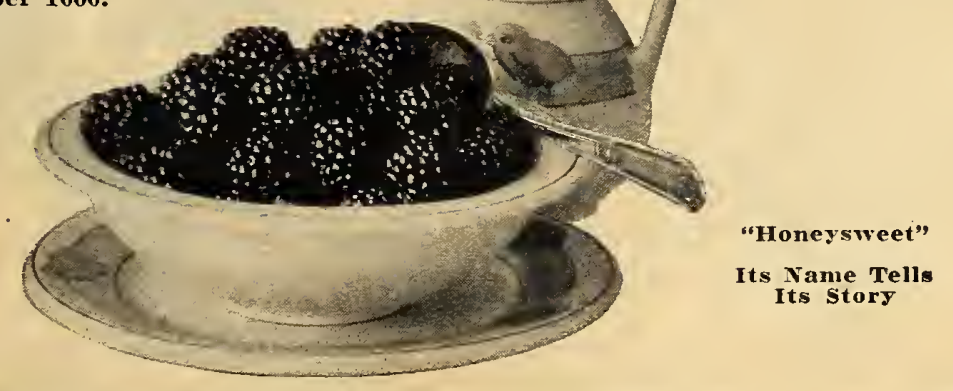




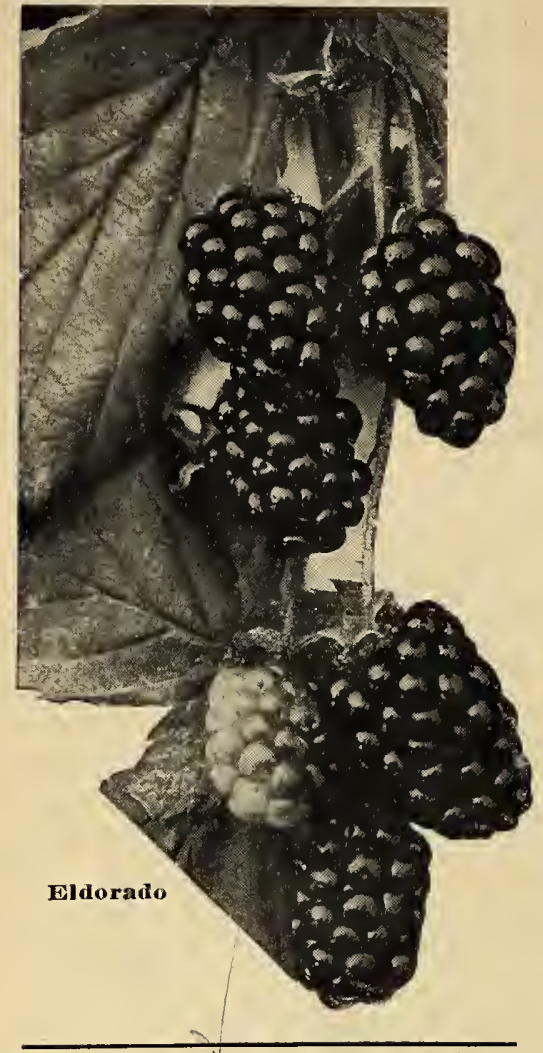

\section{Alfred}

\section{A Big Berry Success}

\section{Sure - to - Grow}

\section{Root Cutting Plants}

Introduced six years ago, it has proven a big success among horticulturists and practical berry growers. It made good from the very start until now the demand is ahead of the supply. And no wonder. Think of a bush full of tremendously big blackberries from $1 \frac{1 / 2}{2}$ to $1 \frac{3 / 4}{4}$ inches long, practically free from seeds, coreless and with a thick pulp fairly bursting with sweet, delicious juice! That's ALFRED!

\section{Enormous Grops Every Year}

The plant is such a vigorous, healthy grower that it produces a good crop the first year after planting. Withstands extreme cold that kills less hardy varieties.

Alfred will please you-whether raised for pleasure or profit. It is another of our splendid varieties-selected for its worth, and is easily grown.

Don't be disappointed-order today.

\section{Blackberries}

Your Profits When Berries Are Scarce -And Prices High

Ripening in August, blackberries are about the fresh berries on the market, and therefore bring

\section{Yes! This is The FamousEldorado}

Every good quality possessed by other blackberries is emphasized in ELDORADO. Its exclusive advantages from Orange Rust; a very heavy Plants are so strong and vigorous they survive verest Northern Winters without mulching. A splencres for commercial purposes. They are making big

Root Cuttings for Big Quick Crops

or best results, plant ELDORADO ROOT CUTTINGS ather than sucker plants. The cuttings are better thrive better even under unfavorable condis. They are well worth the small additional cost cially adapted to home gardens, where strong growing plants and quick $\mathrm{i}$. RootCutting Prices
yields are wanted. Send your order at $\$ 3.25$ Per -. 100 onee as our supply is $\$ 20.00$ Per - - 1,000
limited.

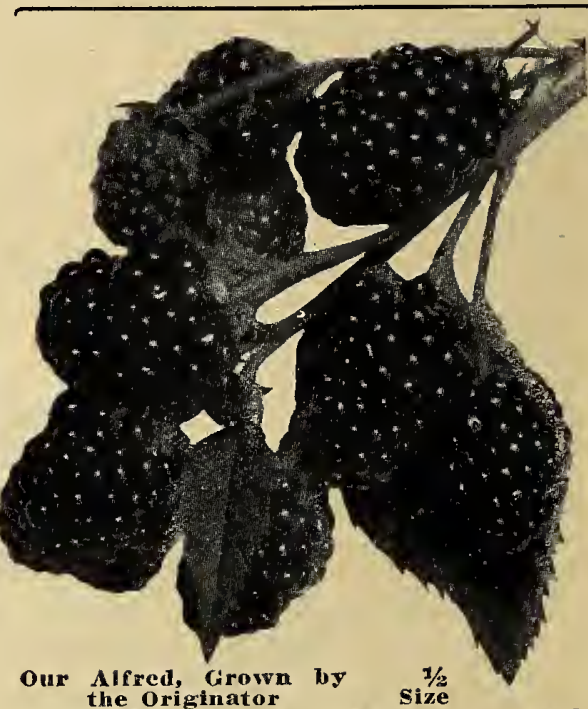

Price, \$5.45 per 100; $\$ 36.00$ per 1,000 . 


\section{Lucretia}

America's Leading Dewberry

Recognized by fruit growers everywhere as the leading Dewberry. Incomparably better in every way than any blacliberry you have ever seen or tasted. For real profit be sure to plant LUCRETIA in field or garden.

\section{An Early Bearer}

Ripens a week to ten days before the earliest ordinary blacliberries. This, and the fact that they are unquestionably the finest looking berry of their kind and of such big, uniform size, makes them top-notchers on price in any market.

\section{Mersereau Blackberry}

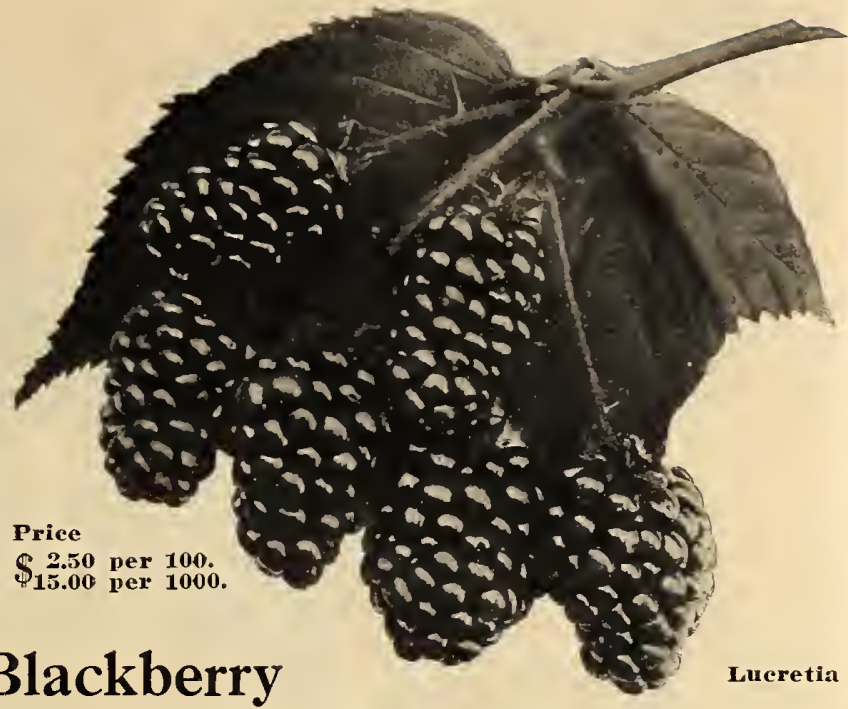

\section{A Favorite Early Variety}

Prices

Root Cutting Plants of 3.25 per 100 . $\$ 20.00$ per 1000 .

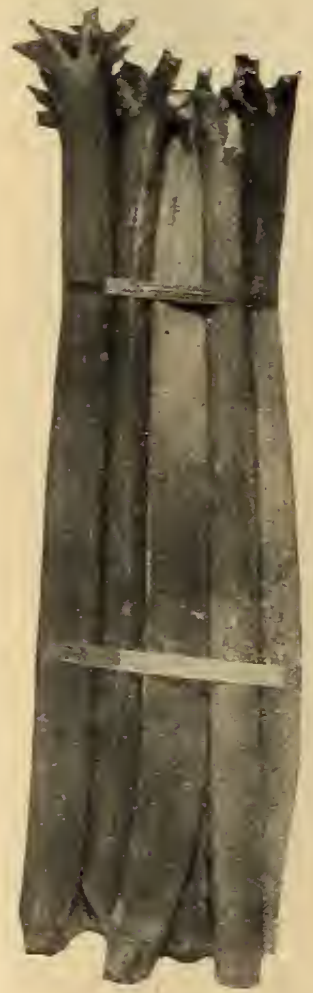

Iratts Victoria The Pink Stalk
Here are a few reasons why Mersereau is being planted in increasing quantities in all fruit sections:

1. Ripens about a week before Eldorado.

2. Splendid in flavor, large, sweet, juicy.

3. Brings better prices because of size, color and flavor.

Bushes are hardy, quick to grow under all conditions, and produce full crops early. You will not be disappointed in Mersereau. Get started this spring with quick bearing root-cutting plants.

\section{There Is a Growing Demand for}

\section{Good Asparagus}

One of the most delicious and healthful garden vegetables. Easy to grow with practically no care. Just plant it, hoe it and eat it. You can quickly have an asparagus bed that will last many years. Such a bed (at least 100 plants) will provide all you want for family use and will give a surplus to sell to local markets or neighbors. There is just one thing-be sure you get a productive kind.

\section{Martha Washington}

Developed by U. S. Dept. of Agriculture. A heavy yielding, pedigreed strain immune to rust: grows rapidly and produces long tender shoots of unexcelled table quality.

NOTE: Two year roots are generally preferred as they are larger, reach full production a whole year sooner, and cost only a little more.

Price (for all quantities see page 34 ) -

1 r. Roots-40e per $25 ; \$ 1.25$ per $100 ; \$ 8.00$ per 1000.

2 yr. Roots-65e per 25; $\$ 1.95$ per $100 ; \$ 12.50$ per 1000 .

\section{Rhubarb}

Tenderest Sweetest Variety

No home garden is complete without Rhubarb. Transplants easily; requires very little attention; produces abundantly. In spring healthful Rhubarb, sauce and pies are most welcome. So be sure to include this Special Offer in your order.

Regular price, $7 \mathrm{c}$ each; $\$ 1.30$ per 25.

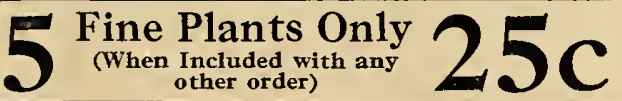

Martha Washington Rust Proof 


\section{Baldwin's Better Grape}

A Permanent Investment-

Paying a Regular Income

For centuries grape growing has been a pleasant and profitable business, but with present day improved hardy varieties and country-wide year-around demand it is not only pleasant and profitable but dependable and permanent as well. Michigan vines rank among the finest grown and because of our specially adapted soil and location, you can depend upon vines.

Superior in Quality and Productiveness

We have grown an extra nice stock of healthy, vigorous vines and are offering them to our customers at unusually low prices.

Grapes grow and produce big crops on any soil, year after year. They are a permanent investment. Grovers regularly make $\$ 500$ and more net profit, per acre, and you can do the same.

\section{Campbell's Early}

Finest Quality Black Table Grape

Unusually large berries make up firm, compact bunches that simply look "quality," and the taste proves it. They ripen two weeks before Concord. For a dozen vines in the fruit garden plant CAMPBELL'S EARLY and know a real eating grape.

Price-2-Yr. Extra Large, 12c each; 70c for 6; $\$ 1.30$ for $12 ; \$ 2.20$ for $25 ; \$ 6.50$ for 100 .

\section{Moore's Early Black Grape}

\section{A Big Crop for Early Market}

A heavy producing early variety. Profitable for commercial growing because it gets the early season high prices. Similar to Concord in appearance and quality, ripening about two weeks earlier. It has a peculiarly sweet flavor that makes it a good table grape along with Campbell's Early.

\section{Worden Black}

Big compact bunches of extra large, thin skinned berries, quality equal to Concord but, because of thin skin, not so good a shipper. Ripens five to ten days earlier than Concord.

Price-2-Yr. Medium, 40c for 6; 70c for 12; $\$ 3.75$ for $100 ; \$ 25.00$ for 1,000 .

2-Yr. Extra Large, $75 \mathrm{c}$ for $6 ; \$ 1.35 \mathrm{for}$ $12 ; \$ 6.85$ for $100 ; \$ 45.00$ for 1,000 .

\section{Niagara}

Most Satisfactory White Grape

This best known and most popular of all white grapes ranks with Concord in prolific bearing, size and quality. An unusually mild delicious flavor makes Niagara one of the finest table grapes.

Medium compact, large bunches; berries mostly round, of greenish-white color, very juicy and of excellent flavor. Skin is thin but tough and does not crack, making it a fine long-distance shipper.

Price-1-Yr. Medium, 40e for $6 ; 70$ e for $12 ; \$ 3.75$ for $100 ; \$ 25.00$ for 1,000 .

1-Yr. Extra Laree, $75 \mathrm{c}$ for $6 ; \$ 1.35$ for 12 $\$ 6.85$ for $100 ; \$ 45.00$ for 1,000
Price-2-Xr. Mediun, $40 \mathrm{e}$ for 6; 70e for 12; $\$ 3.75$ for $100 ; \$ 25.00$ for 1,000 .

2-Yr. Extra Large, 75e for 6; $\$ 1.35$ for $12 ; \$ 6.85$ for $100 ; \$ 45.00$ for 1,000 .

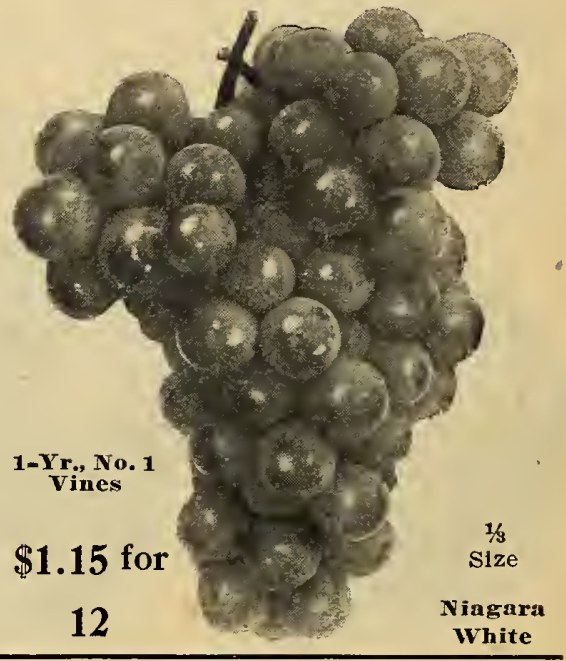

Page 19 


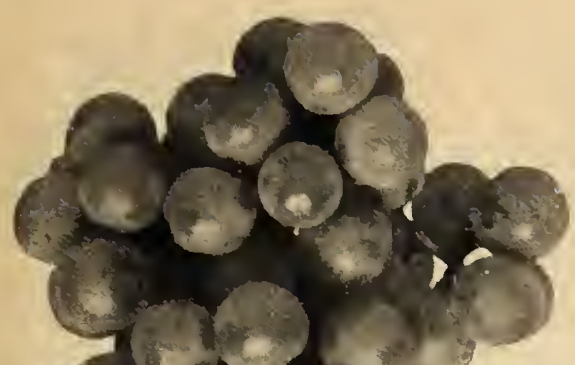

\section{New Caco Red Grape Has Earned Our Unqualified Recommendation}

As we do with every fruit, we have waited to offer Caco until certain that it was A-1 in every respect. We can now give it our unqualified approval. It is hardy, quick bearing, produces every year, fruit beautiful in color, unusually large in size, and best of all has a flavor of such sweetness that it is a superior table grape.

In fact, one of the strong points of Caco is that it contains so much sugar as to be readily eaten while still green and long before it appears ripe.

\section{Very Early-Heavy Bearer-Superior Quality}

Bunch is firm and compact-berries unusually large, clear amber in color. Caco is a most beautiful hardy grape. Always in demand at grape markets with extra prices. Widely endorsed by experiment stations.

Vines are just as easy to grow as any other. There is always room for a few vines somewhere. You don't want to be without Caco.

Our supply of this new grape is limited-order yours at once.

\section{Delaware Red}

\section{Flavor Unsurpassed}

Long called the standard of excellence of all grapes as a table delicacy. Bunch small, compact, sometimes shouldered; berries small with skin thin and of unusually sweet flavor. Ripens with Concord. Very hardy.

It is impossible to tell you how really delicious these little red grapes are. Don't fail to plant a few vines this spring. Just a little space over the back porch or on a trellis along the garden wall is enough for 5 or 6 vines.

Price-2-Yr. Medium, 15c each; 80c for 6; $\$ 1.50$ for $12 ; \$ 2.70$ for $25 ; \$ 8.50$ for 100 .

\section{Agawam-Red Grapes}

Probably the best big, red grape. Large bunches of big berries, of excellent flavor. Delicious for home and table. Very productive; good shipper; rapidly growing in commercial demand and very profitable:

Price-2-Yr. Extrat Large, 13e each; 75e for 6; $\$ 1.40$ for 12; $\$ 2.50$ por $25 ; \$ 7.50$ for 100 .

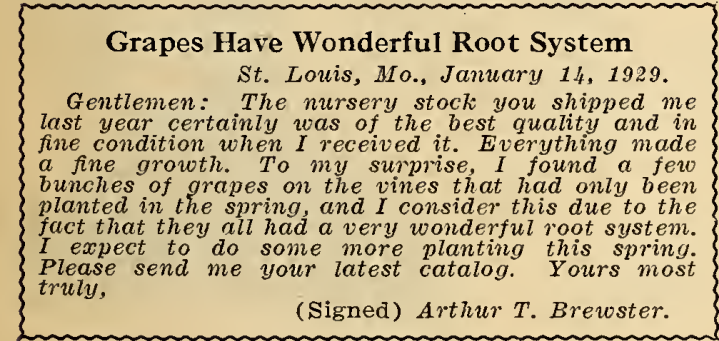

Special Selected Plantings Pages 37-38
Price 1-Yr. Extra Large, 40e $12 ; \$ 7.35$ for 25

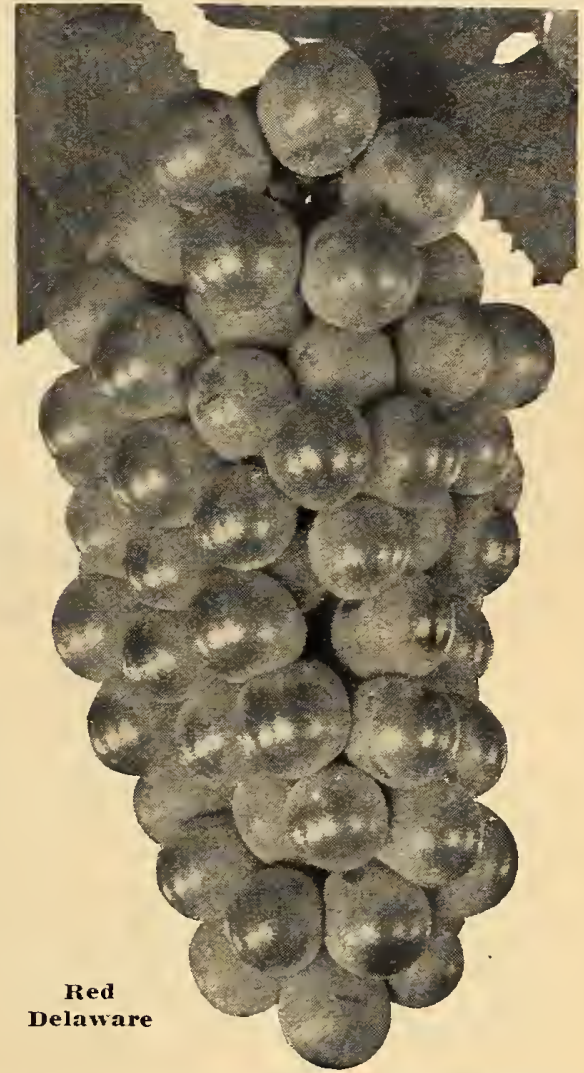




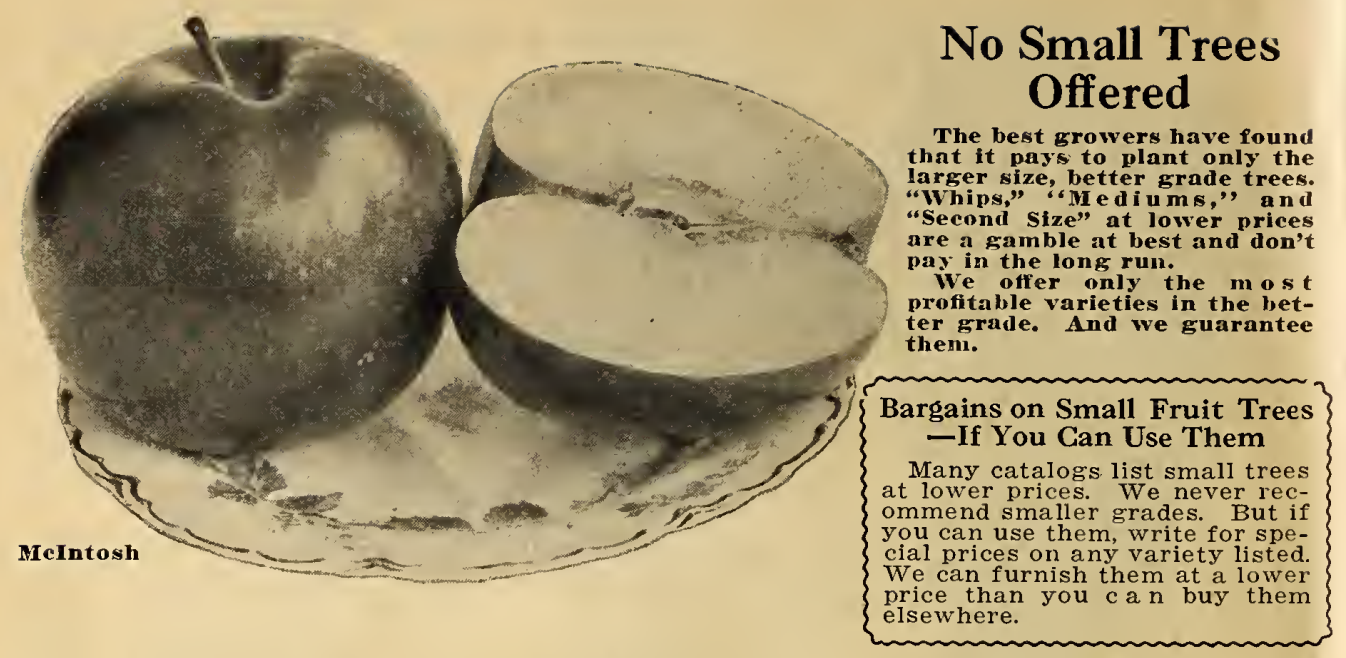

\section{Baldwin Quality Fruit Trees}

Guaranteed, 'Hardy, True-to-Name, Productive Buy from Us and Save Half of Agents' Prices

Whether you want only a few trees for a home fruit yard or several hundred for a commercial orchard, we can supply you with well grown, strong, sturdy trees. Our prices are less than half the usual prices asked by agents, because we sell direct from Nursery to you. And, what's more, we stand back of the trees after you get them.

There is real pleasure and a big saving in having 2 or 3 trees of each kind of fruit right in your garden. As a commercial proposition, tree fruit is always in demand and with modern storage practices, prices are kept high.

Especial care is given to the selection of those high-quality, proven-value varieties which are best adapted to eastern, middlewestern and northern soils and climatic conditions. We have no hesitancy in guaranteeing them. Don't wait to set fruit trees-they are a good investment in garden or orchard. Plant this spring.

\section{A Word About Right Grading}

Trees are graded either by caliper or by height. Ours are carefully graded by both measurements-because we want you to have trees that are not "short" either in height or in sturdiness. Every tree must be $9 / 16$ ths inches in diameter and 5 to 6 feet high. This insures our customers trees of good height yet not spindly, (as would be the case if graded for height only). Every tree we ship has a good sturdy trunk and root system capable of carrying it to full growth even through unfavorable conditions.

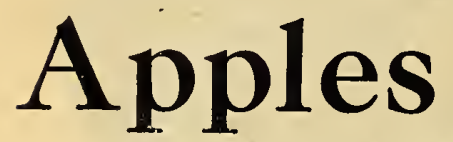

$35 \mathrm{c}$ each.

$\$ 3.25$ for 10 . $\$ 30.00$ for 100 . ( 2 yr. 5 to $6 \mathrm{ft} ., 9 / 16$ in. Caliper Trees)

\section{Mc Intosh}

\section{A Most Profitable Apple Today}

Juicy snow apple-white crisp flesh; beautiful solid crimson color. Excellent quality-wine-like, true apple flavor. Good annual bearer. Rapidly increasing popularity among consumers everywhere makes good prices certain. One of the most profitable apples today.

For your information-we have carefully investigated the Cortland apple so widely advertised by many nurseries. Several experiment stations have advised us that McIntosh is superior and probably will never be replaced by the newer Cortland. Because of their advice we offer only McIntosh, and you can be assured it is unsurpassed in its class.

"Red Delicious", Color Illustration-Page 40

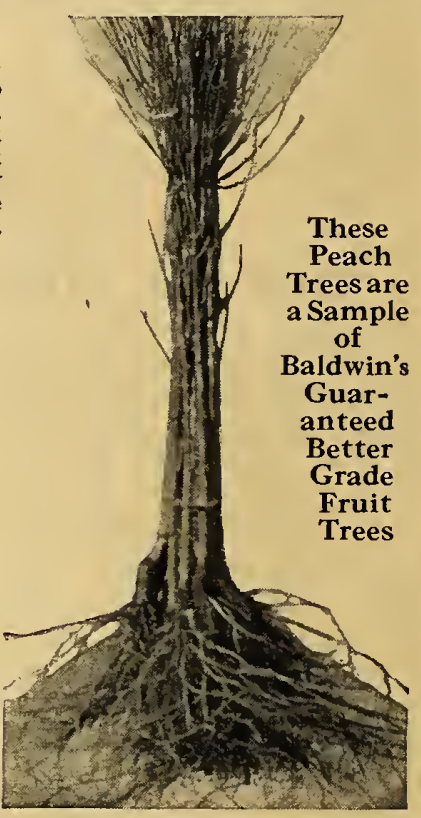

Note sturdy tops; branched fibrous roots 


\section{Stayman's}

Best of All Winesaps

Late Winter. Extra large, bright red, crisp, juicy with a wonderful zestful flayor. Stayman e a sily leads all other Winesaps. H e a v y bearers and big money makers everywhere.

\section{Baldwin}

Winter. This wi d e ly known variety a verages above medium size, rich dark red, juicy, fine flavor. Good for market and home use. One of the first two or three varieties in the great Michigan a $\mathrm{d}$ New York apple sections.

\section{Northern Spy}

winter. The old, well-known favorite. Delicious spicy flavor; excellent for eating and cooking. Brilliant streaked red color. Always in demand at good prices. Long keeper.

\section{Grimes Golden}

Winter. Favorite mild eating apple. Excellent keeper. Uniform shape, typical dull gold color. Hardy, productive tree. Carefully selected and grafted trees insure entire satisfaction with this fine apple.

\section{- Wealthy}

Fall. Heavy y e a r y bearer. Hardy, long lived. Attractive brilliant red striped; superb quality, wine-like flavor. An all around apple for eating, cooking, cider and market.

\section{Jonathan}

\section{In Demand from Coast to Coast}

Late Fall. Glossy red; fine grained, juicy flesh, excellent flavor. Medium to large size. Unusual keeping quality (to February) makes it a most profitable commercial apple. Quick to bear and easily grown in practically every fruit section. Jonathan is the first choice in many homes.

\section{Yellow Transparent}

Early Fall. Has proven both popular and profitable. Fruit large, yellow with crisp sub-acid flavor. Heavy annual bearer; well known everywhere.

\section{Duchess of Oldenburg}

Summer. Yellow, streaked $\mathrm{w}$ it h red. White, juicy flesh and wonderful flavor make it famous everywhere. Trees are dwarf growers requiring small planting space. Fine for early market and home use.

\section{Hyslop Crab \\ The Best Variety}

Hyslop is recognized as the best of all crabapples. Its hardy, quick growing tree comes into bearing early. Strong, diseaseresistant. Always a heavy annual bearer. Fruit beautiful deep red; firm, juicy, uniform-sells well. Excellent for home use.
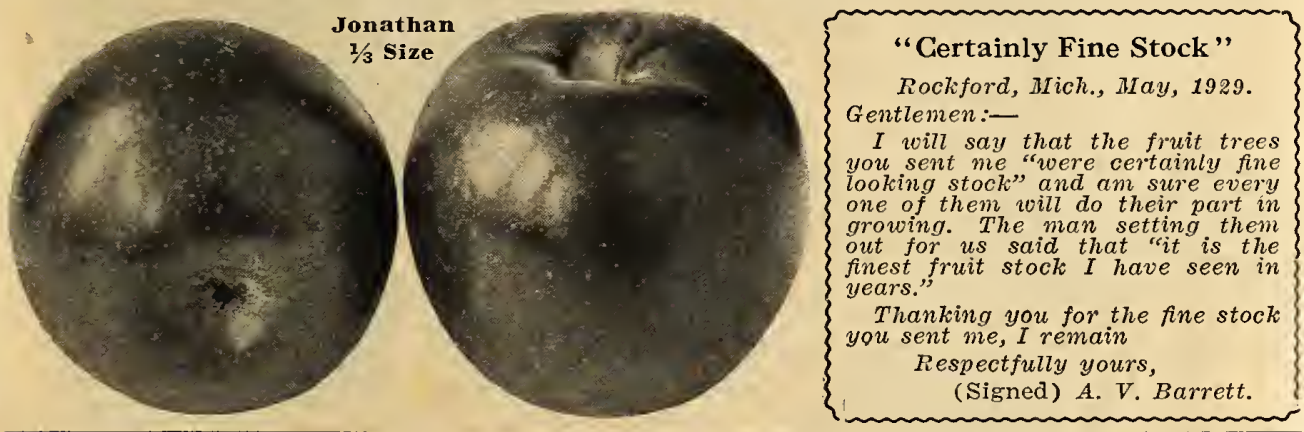


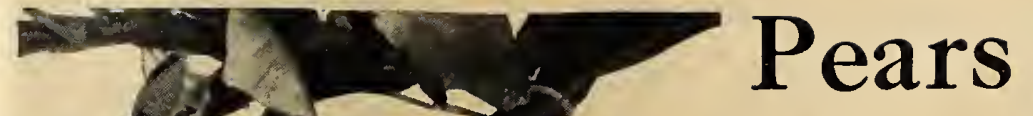

$50 \mathrm{c}$ each

$\$ 4.75$ for 10 $\$ 45.00$ for 100

( 5 to $6 \mathrm{ft}$. trees, $9 / 16$ in. caliper)

Clapp's Favorite-Summer. Ripens August 1st. A seedling of Bartlett but e a $\mathrm{r}$ l i e r ripening; somewhat larger; lemon yellow; of very good eating quality.

Anjou-(Buere d'Anjou)-Fall. Prime from late October to late November. Greenish yellow; clear, white flesh of splendid eating quality. Stored in a cool, dry place will keep until Christmas. Strong vigorous tree; prolific yielder.

Seckel-Early Fall. A medium sized pear that ripens late in September. Extremely fine quality and flavor. Always in market demand and equally valuable for home use.

Duchess D'Angouleme - Late Fall. Fruit large, frequently a pound in weight. Most dependable crops. Dull greenish yellow with russet spots; flesh white, rich and good quality. Duchess is a profitable, all around market pear.

Kieffer-Fall. Best pear for large commercial planting, because of its sure crop,

\section{Bartlett Pear}

\section{The Standard of Quality}

Summer. One of the best known and popular varieties for both commercial and home orchard planting. Golden color with red streak, mellow and indescribably delicious both fresh and canned. Produces enormous crops; bears early. If picked before ripe will keep until late.

\section{Lombard Plum}

\section{Leading Market Variety}

H e a y regular bearer of medium sized red-purple f r u i t of excellent quality. A dependable pl u m everywhere and always commands good prices because it is widely a $\mathrm{n}$ d favorably known. Ripens August.

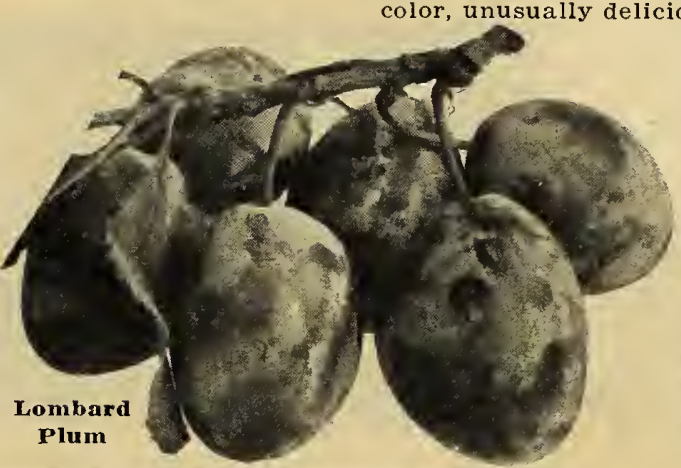
heavy yield and exceptional shipping qualities. Kieffer has proven unexcelled for commercial canning. A local cannery used over 200,000 bushels last fall.

\section{Plums ${ }^{45 c}$ cach Plums $\$ 4.25$ for 10 (5 to $6 \mathrm{ft} .9 / 16$ in. trees)}

Monarch-widely Grown and Profitable. This strong tree is a heavy bearer of finest plums. Very large, entirely free-stone, dark purple blue color, splendid flavor and quality. Ripens in October. Brings f a $\mathrm{n} \mathrm{cy}$ market prices. None better for home use-fresh jelly or canned. Ripens October.

Burbank-Delicious Table Plum. A strong, hardy Japanese variety. Practically curculioproof and free from black lnot. Deep red
color, unusually delicious flavor. Keeps three weeks after ripening. Trees bear three to four years after planting. Ripens August 15 to September 1 st.

Ge rman Prune -Best for Canning and Preserving. Medium sized, dark purple plum. Firm, sweet; the favorite everywhere for canning. Tree easy to grow and remarkably free from disease and very productive. Good keeper, excellent shipper. Ripens, September. 


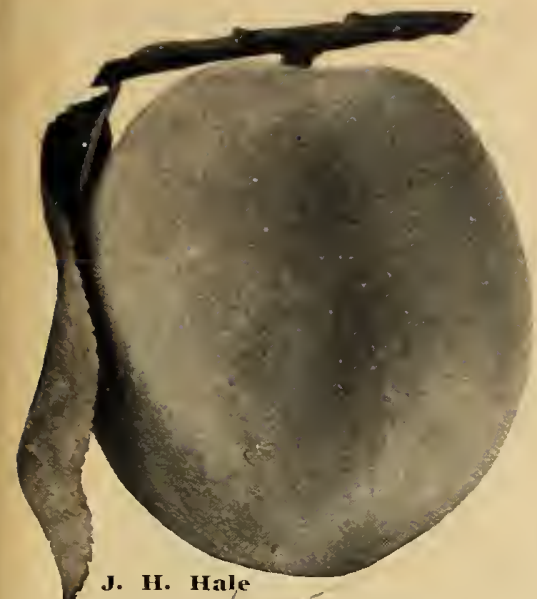

Peaches

Except South Haven $-40 \notin$ Each

( 5 to $6 \mathrm{ft}, 9 / 16 \mathrm{in}$. caliper)

Elberta, Rochester and Gold Drop, full color, Page 40

\section{J. H. Hale}

\section{Unexcelled in Size, Color and Quality}

Late August-Yellow, extra large; thick skin; colors to a rosy tint. Deep yellow, fine grained, very firm flesh of excellent quality. Truly a beautiful peach either fresh or canned. In size, color and quality, no peach compares with J. H. Hale. Always brings $\$ 1.00$ to $\$ 1.50$ more per bushel.

\section{South Haven}

\section{Now the Profitable Early Peach}

Originated and developed in the famous Michigan Peach Belt, South Haven has proven one of the best varieties in every peach growing section. Experiment stations recommend it when an earlier peach than Elberta is desired. It is also a more hardy variety than Elberta standing severe winters better. As fine a peach as the standard Elberta, big, firm, highly colored, but more dependable for big crops in cold sections-and Ripens 12 to 18 Days Earlier. An early peach is always profitable but an excellent peach like South Haven is doubly so. Don't fail to plant now.

Early Crawford-Early September-Widely planted; large size, well colored; good flavor. Freestone, good canning and market variety.

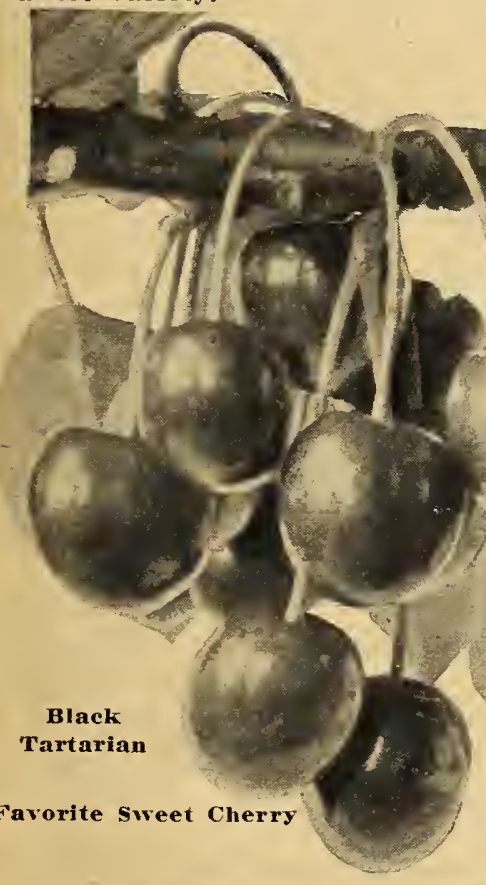

Név Prolific-Late Augnst-A fine canning peach. Delicious mild flavor; cl e a $r$ yellow color; average size; freestone. Regular annual bearer.

Kalamazoo: Late August-Medium size, oval, yellow skin, yellow red flesh, freestone of excellent quality. A fine peach for dessert, pies and canning and for market.

\section{Sweet Cherries}

\section{$60 \AA$ each $-\$ 5.50$ for $10-\$ 50.00$ for 100}

(5 to $6 \mathrm{ft}$., $\% 16$ in. "caliper)

(Sour Cherries in color, Page 40)

Bing-Large, firm black cherry. Splendid slipper. Hardy tree; upright grower. Ripens middle of June.

Windsor-Liver colored, large cherry, wonderful flavor. Originated at IVindsor, Canada. Hardy prolific tree. Most valuable variety for market or family use.

Black Tartarian-Extensively planted and prolific. Regular bearer of big, black, juicy, sweet fruit. Hardy, vigorous. Best and most profitable black sweet cherry-for market, cooking, canning.

Napoleon-Yellow-Old time favorite, succeeds practically everywhere. Heavy bearer of large, light yellow, heart-shaped fruit. 


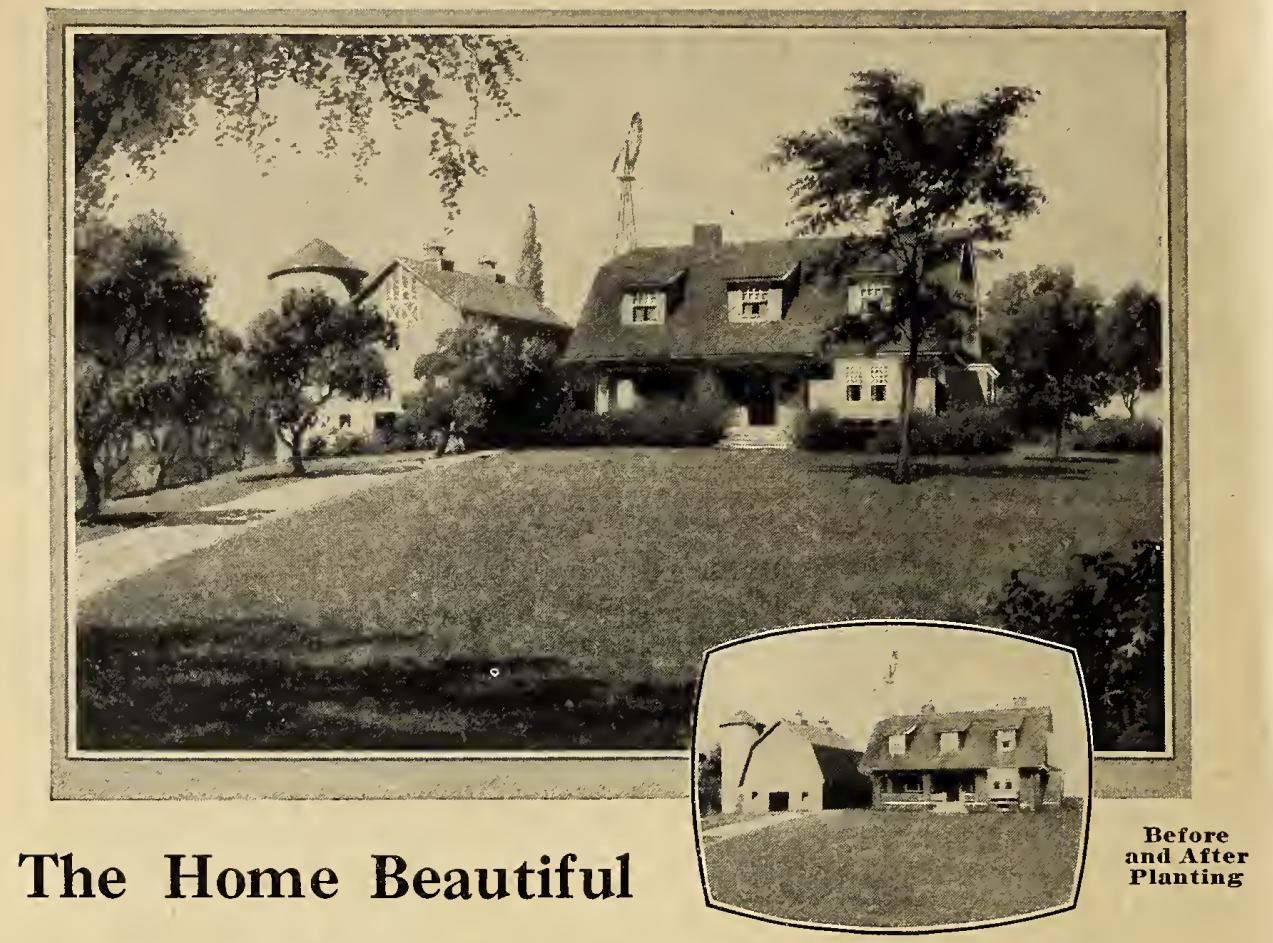

\section{Plant Shrubs, Roses, Flowers, Shade Trees, Evergreens}

\section{Enjoy a Beautiful, Well-Planted Home - It Costs Little}

Today, home planting is the thing that every up-to-date, progressive man and woman is discussing, planning and doing. It's the subject of the hour on the farm, in the village and in the city. They recognize it as the right thing because it gives them the utmost in health, beauty and happiness. At the same time it is a practical investment through increased value.

\section{$\$ 10$ Spent in Planting Adds $\$ 100$ in Value}

Statistics show this is the value real estate men put on planting. Our ornamentals are wonderfully fine stock, and in selling them direct to you we save you half what agents ask. So a complete planting costs you but little.

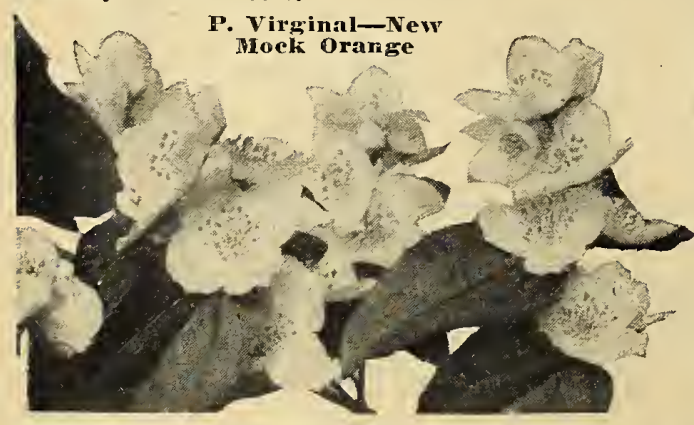

\section{An Outdoor Living Room}

Your farm home should have an outdoor living room. 'Nothing else will add so much to the pleasures of farm life, and to the actual cash value of every acre of your farm, as an Outdoor Living Room.

No other improvement costs so little and none gives so rich a return in happiness, health and contentment.

Your outdoor living room, with lovely trees, shrubs and evergreens giving shade, privacy, and screening out objectionable views-with hardy flowers adding cheerful touches of color and lovely fragrancehas a never-ending appeal for every member of the family.

\section{Free Landscape Suggestions}

We will gladly send planting suggestions for your home if you will send us a rough sketch of the location and measurements of buildings, drives and present plantings. The sooner you do this the more time we will have to help you before our busy season.

\section{Mock Orange - P. Virginal}

\section{New Variety of Unusual Beauty}

A magnificent new variety. Medium height, compact bush. The flowers (single, semidouble and fully double) are the largest and most sweetly fragrant of any variety, with longest early blooming season. Gaining popularity in every state.

Price, 1 1/2 to $2 \mathrm{ft}$., each, $40 \mathrm{c}$; $\$ 2.20$ for 6. 


\section{Mock Orange-P. Coronarius}

A large, very hardy shrub which has a profusion of pure white, highly scented flowers. Attains a height of 4 to 6 feet. Blossoms in June.

Price, 1 1/2 to $2 \mathrm{ft}$., each, 12c; 70c for 6.

\section{Forsythia}

F. Fortunei. One of the first shrubs to bloom. Their bright yellow flowers seem the very spirit of Spring, opening before the leaves appear. Will reach a height of 6 to 8 feet but may be pruned to desired height; branches slightly drooping. Dark green leaves. Flowers hauntingly sweet.

Price, $1 \frac{1}{2}$ to $2 \mathrm{ft}$., each, 15c; $80 \mathrm{c}$ for 6 .

\section{Spirea Van Houtei}

One of the most beautiful and popular of flowering shrubs. In May and June the slender branches droop and form a veritable fountain of snowy white bloom. Thrives anywhere, in shade or sun, wet or di'y and grows from 6 to 8 feet high in good ground. Makes a beautiful ornamental hedge.

Price, 1 1 1/2 to $2 \mathrm{ft}$., each, 12c; $70 \mathrm{c}$ for 6.

\section{Spirea Anthony Waterer}

Dwarf hardy shrub; large pink-red flowers 3 inches across. Blooms July to frost. Rarely reaches over 3 feet; good used as edging for taller shrubs.

Price, 1 恬 to $2 \mathrm{ft}$., each, $40 \mathrm{c} ; \$ 2.20$ for 6.

\section{Spirea Arguta}

One of the showiest of spring shrubs. Dense masses of white flower clusters along drooping branches. Leaves light green, narrow-giving a lace-like beautifully soft appearance. April-May bloom.

Price, $11 / 2$ to 2 ft., each, 25c; $\$ 1.40$ for 6 .

\section{Deutzia}

Pride of Rochester. The large double white flowers, reverse side of petals a delicate pink, make this a most highly prized shrub. Fine specimen plant 6 to 8 feet high. This Deutzia deserves a much wider use. Blooms June-July.

Price, 1 1/2 to $2 \mathrm{ft}$., each, 12c; 70c for 6.

\section{Privet Hedge}

\section{Hardy Amoor River North}

Excellent hedge plant. Especially desirable in the north because of its unusual hardiness. Absolutely does not winterkill. Leaves are dark; do not fall until late winter. Readily trimmed to any desired shape.

Price, 11/2 to 2 ft., each, 12c; $\$ 1.30$ for 12 ; $\$ 9.00$ for 100 .

\section{Japanese Barberry}

\section{For Every Purpose}

Where a beautiful foliage effect is desired there is no shrub so generally planted or more practical for all purposes than the JAPANESE BARBERRY. Dwarf g r ow ing, bushy and rounded in form. of special importance for use as a filler, a $\mathrm{nd}$ edging for shrubbery groups, and above all as a compact, low hedge for lawn borders. In autumn the foliage turns scarlet and gold covered with crimson berries.

Price, $1 \frac{1}{2}$ to $2 \mathrm{ft}$, each, $18 \mathrm{c} ; \$ 1.85$ for $12 ; \$ 14.00$ for 100 .

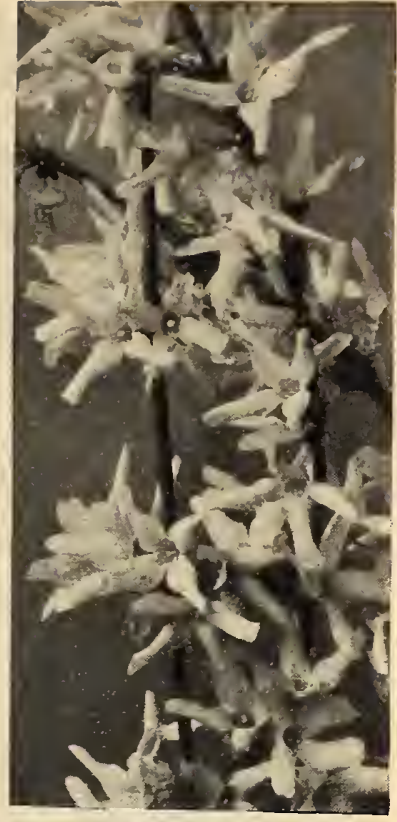

Forsythia

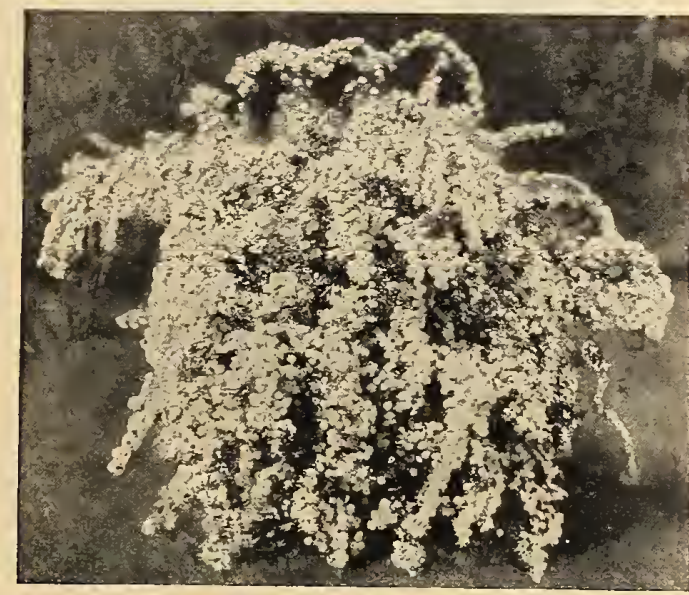

Spirea Van Houtei

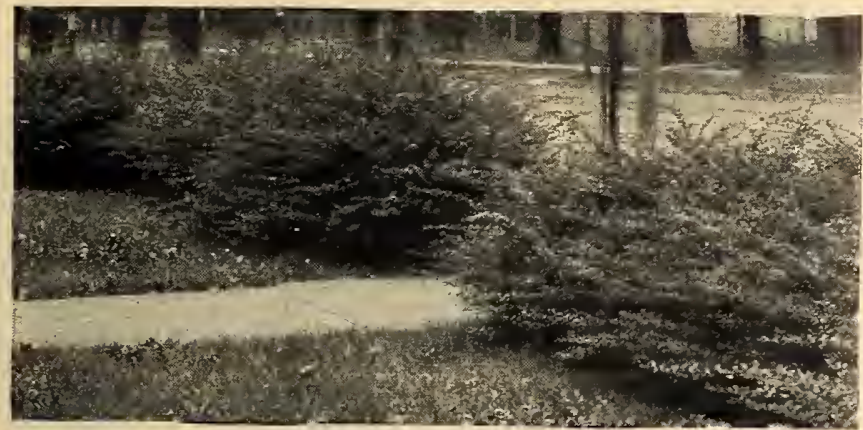

Japanese Barberry 



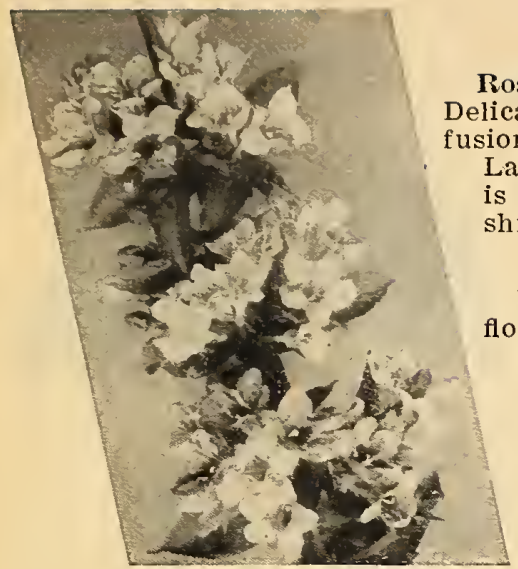

Weigela Rosca

\section{Butterfly Bush}

A beautiful medium size shrub that bears clusters of lilac-colored flowers, 5 to 6 inches long. Attracts butterflies in large numbers. Blooms early summer until late in Fall.

Price, 11/2 to 2 ft., each, 25e; $\$ 1.40$ for 6.

\section{White Snowberry}

Distinguished for its graceful sprays of large, milk-white berries coming in mid-summer and lasting well into winter. Added effect of soft green foliage makes this one of the most attractive ornamental shrubs. 4 to 5 feet.

Price, 11/2 to 2 ft., each, 20c; $\$ 1.10$ for 6.

\section{Red Snowberry}

Coralberry. Desirable for its clusters of red berries, hanging on all winter. Low growing, graceful, spreading habit. Attractive foliage; sturdy grower in shade.

Price, $1 \frac{1}{2}$ to 2 ft., each, 20e; $\$ 1.10$ for 6.

\section{Golden Elder}

Showy, golden leaves; tall, sturdy, hárdy shrub. Just right where height and color are needed. Unusually large clusters of white fragrant elder blossoms, followed by black berries. Attractive ornamental shrub. $7-10$ feet; blossoms August.

Price, 2 to 3 ft., each, $40 \mathrm{c} ; \$ 2.20$ for 6 .

\section{Bechtel's Flowering Crab}

A flowering tree of outstanding beauty Large, apple-pink, double, fragrant blossoms. Adapted to single planting-grows 8-10 feet high. Slower growing, longer lived ornamental tree well worth the added cost.

Price, 2_to $3 \mathrm{ft}$. each, $70 \mathrm{c} ; \$ 3.50$ for 6.

\section{"SHRUBS"' By F. F. Rockwell}

Brief but complete information for improving the beauty and value of your home with shrubs. Tells what to select for different combinations and effects; how to plant, prune and care for shrubs, 49 illustrations, 76 pages.

Price, postpaid, \$1.15.

\section{Weigelas} ink. 4 to 5 feet. The most popular Weigela.
$k$, bell shaped blossoms are borne in great progreat arching canes, during May and June. es especially free from disease. This variety est of the group and is good for all use where a $f$ this height is needed.

Veigela Eva Rathke-Crimson. $3 \frac{1 / 2-4}{\text { feet. June }}$ . Of smaller growth than the other Weigelas. with white A profusion of fowers bril acteristic. It is especially showy and will prove excellent variety.

rice, $1 \frac{1}{2}$ to $2 \mathrm{ft}$., each, $40 \mathrm{c} ; \$ 2.20$ for 6.

\section{Flowering Almond}

Rose-pink flowering-3 to 4 foot, upright grower. A very attractive shrub. The long branches are thickly studded with small double, delicate pink flowers over their full length, before the leaves appear. Blooms in April.

Price, $11 \frac{12}{2}$ to $2 \mathrm{ft}$, each, $40 \mathrm{c} ; \$ 2.20$ for 6 .

\section{Japanese Quince}

Flowering Quince-Scarlet flowers-6 to 8 feet. Blooms in April and May. One of the mest attractive spring blooming shrubs; blossoms always large, produced in great masses just as the leaves a re coming out. Foliage is a dark, glossy green. A favorite flowering shrub that should be in every garden.

Price, $11 / 2$ to 2 ft., each, $40 \mathrm{c} ; \$ 2.20$ for 6 .

\section{Coral Dogwood}

C. Siberica. Bright red branches and berries make it attractive in winter. A valuable shrub because it grows vigorously in shade. Large leaved foliage makes a good show in summer and fall. 6 to 10 feet.

Price, 11/2 to $2 \mathrm{ft}$., each, 20c; $\$ 1.10$ for 6 .

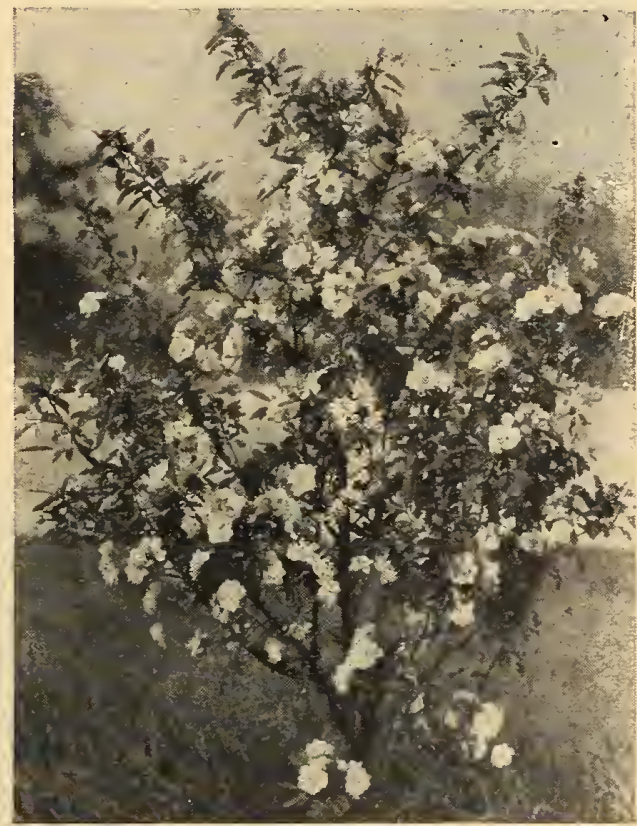

Bechtel's Flowering Crab 


\section{Evergreens}

\section{Suitable for Every Home Provide All Year Beauty}

In the last few years the value and desirability of Evergreens for all kinds of ornamental planting has been realized by home owners. The increase in demand for the finer varieties has been enormous.

There is some place in every home where nothing will quite take the place of an Evergreen. Their beautifully colored foliage is outstanding in summer; in winter many a harsh landscape is made truly beautiful. In all seasons Evergreens present a pleasing appearance-a warm welcome-and are thoroughly worthwhile.

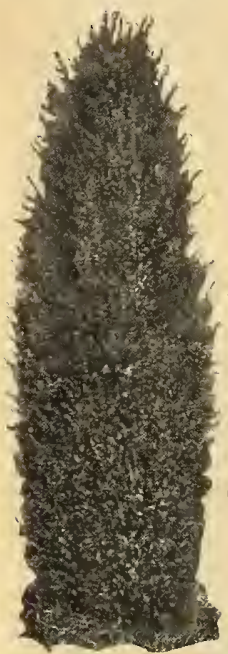

Irish Juniper

\section{Wide Range of Shapes,} Colors and Uses

Evergreen specialists have perfected fine varieties in all kinds of shapes,

\section{Irish Juniper}

This upright, decidedly column-like form is ideal for formal effects and just the thing to bring out other plantings by contrast. Grows 6 to 8 feet in height and not over $1 \frac{1}{2}$ feet in diameter. Color is bluegreen. Grows sturdily in poor soils and is fairly tolerant of shade.

"Evergreens for the Small Place"

By F. F. Rockwell

All needed information to make the best use of Evergreens. Written by one who is himself a hone owner. It tells the uses and types of small or dwarf Evergreens, and planting and gen e r a care. 67 illustrations, 84 pages.

Price, postpaid, \$1.15.

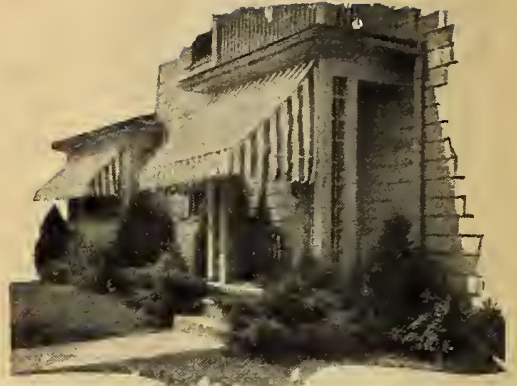

colors and sizes. Select the right tree for plantings at doorways, about foundations, in groups, as wind-breaks or as single lawn specimens. Shapes range from the low spreading Pfitzer's Juniper, through globe and upright kinds to the great pines and spruces. In color, you have your choice running from brilliant golden through yellow green and delicate blue to deep green.

\section{Modern Planting Requires Evergreens}

Every up-to-date planting includes some Evergreens-not because it is the "style," but because they are worthy and well qualified for landscape uses. Evergreens give a certain sense of pride, permanence and satisfaction that no other shrub or tree does.

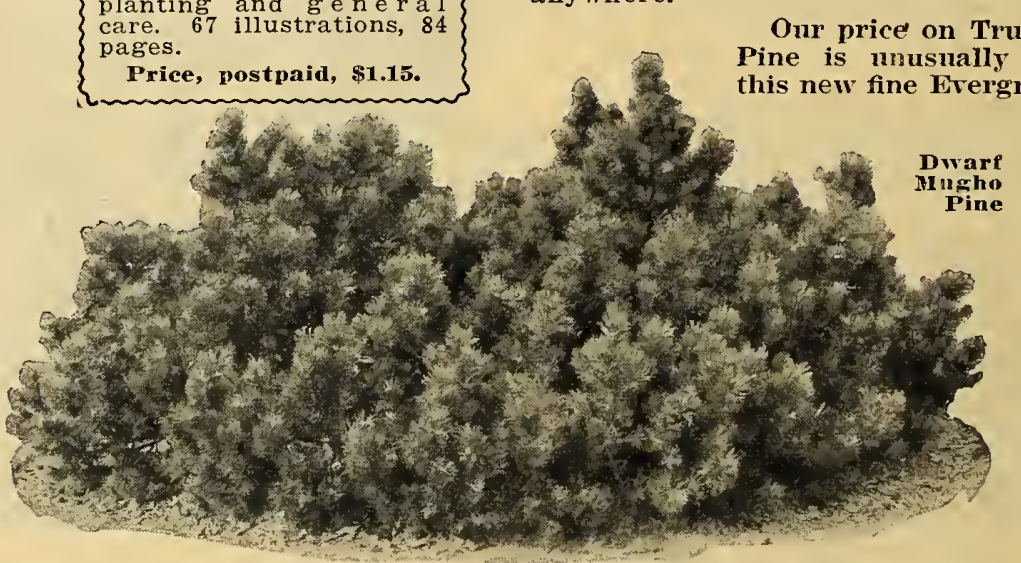




\section{Genuine Colorado Blue Spruce Nature's Most Beautiful Everǵreen}

Imagine a straight, perfectly shaped, gradually tapered tree with heavy foliage from ground to tip of brilliant, glistening steel-blue-and you have a faint picture of this beautiful tree. Best used as a specimen set alone; also attractive set in a dark green background for contrast.

There have never been enough true blue specimens for the demand. It is always a highly prized tree and you should take this opportunity to secure one or more. Our supply is limited.

\section{Norway Spruce}

Most planted of all spruces because of its graceful form, deep green foliage, rapid growth and hardiness. Its even, regular growth makes it suitable for ornamental specimen or hedge use. Nothing better for screens and wind-breaks. One of the most beautiful large evergreens, with its graceful, drooping branches. Grows vigorously in all locations.

\section{Douglas Fir}

A typical fir in rugged, sturdy growth in any situation. Especially adapted to landscape planting because its dull green short needles and compact growth give the suggestion of softness as contrasted with the stiff harshness of the spruces. Lower branches horizontal or even drooping; higher ones upright and the top sharply pointed. Reaches 60 feet or more with spread of 10 to 18 feet. A rapid grower.

\section{Pfitzer's Juniper}

Particularly adapted to landscape use in small or large grounds. Unknown a few years ago, this tree is today one of the most desired ornamental evergreens. Low and spreading growth, s of t wavy branches, deep green in color with greyish cast. Just the right variation in doorway, foundation or bed plantings, contrasting with the upright growers. Don't fail to set two or more.

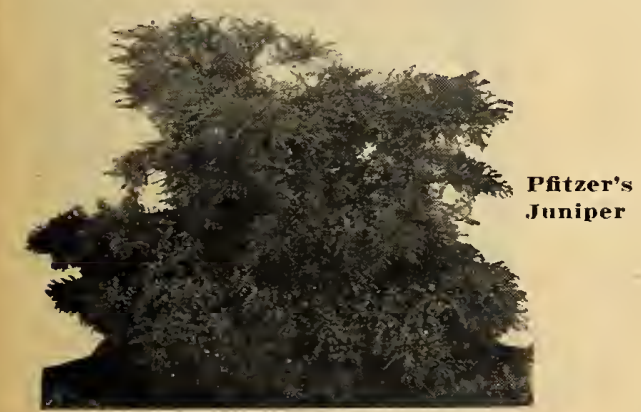

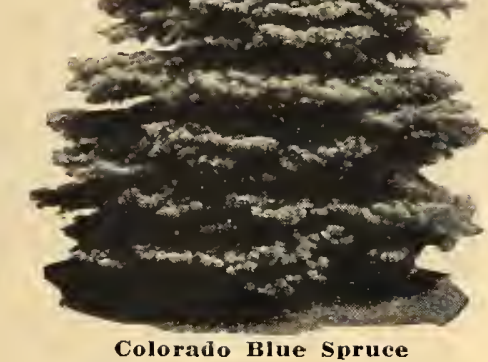

\section{Pyramidal Arbor Vitae}

Well known and always attractive. Of dense, compact growth and narrow, pyramidal form, sometimes reaching 15 feet, but rarely more than 2 feet in diameter at the base. Deep, rich green foliage. Often used at corners, pillars and as a background for smaller evergreens. Easy to transplant and very hardy.

\section{Hovey's Golden Globe Arbor Vitae}

Unusually striking beautiful divarf formone of the best. Foliage is golden yellow, fine and soft in appearance. Particularly desirable for foundations and window-boxes. A true globe type and deservedly popular.

\begin{tabular}{|c|c|}
\hline EVERGREEN PRI & \\
\hline $\begin{array}{c}\text { Every Tree Balled and Bu } \\
\text { for Safe Shipment }\end{array}$ & pped \\
\hline Express Shipment only on Evergr & \\
\hline Colorado Blue Spruce- & $\mathbf{3}$ \\
\hline $11 / 2$ to $2 \mathrm{ft} \ldots \ldots \ldots \ldots \ldots \$ 5.75$ & $\$ 15.75$ \\
\hline Douglas Fir $-11 / 2$ to $2 \mathrm{ft} \ldots . \mathbf{3 . 5 0}$ & 0.75 \\
\hline Golden Globe Arbor Vitae- & \\
\hline 12 to 15 in. (Dwarf) .... $\mathbf{1 . 7 5}$ & 4.80 \\
\hline $\begin{array}{l}\text { Irish J uniper-1 } 1 / 2 \text { to } 2 \mathrm{ft} \ldots \mathbf{1 . 7 5} \\
\text { Mugho Pine-1 to } 11 / 2 \mathrm{ft} \text {. }\end{array}$ & 4.80 \\
\hline (Dwarf) $\ldots \ldots \ldots \ldots \ldots$ & 10.50 \\
\hline Norway Spruce-11/2 to $2 \mathrm{ft}$. 1.50 & 4.00 \\
\hline $\begin{array}{l}\text { Pfitzer's Juniper }-1 \text { to } 11 / 2 \mathrm{ft} \text {. } \\
\text { (Dwarf) } \ldots \ldots \ldots \ldots \ldots \ldots \ldots \ldots\end{array}$ & 9.75 \\
\hline Pyramidal A & \\
\hline 1.75 & 4.80 \\
\hline
\end{tabular}




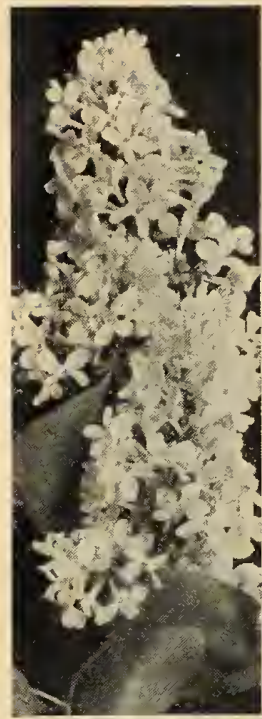

Persian Lilac

Choicest variety-unu sually large, pale li l a c blooms, sweetly fragrant. Everybody admires the lilac. Practically every yard should have 2 or 3 of these popular shrubs.

Price, 2 to $3 \mathrm{ft}$., each, $40 \mathrm{c} ; \$ 2.20$ for 6 .

\section{Bush Honeysuckle}

Red Tartarian. This vigorous $\mathrm{s} p \mathrm{read}$ in shrub with dark green f o l i a g e bears large, bright $r$ e d flowers in June and, later in the season, crimson berries. V e ry showy. Height, 6-10 feet.

Price, $1 \frac{1}{2}$ to $2 \mathrm{ft}$., Persian Lilae each, 12c; 70c for 6.

\section{Althea-Rose of Sharon}

Beautiful deep pink flowers; dark green, glossy foliage. Great masses of large flowers 3 inches across in August and september when there are few other flowers. Hardy; succeeds anywhere. Plant the bush form (grows to 4-6 feet) in beds; the tree form (reaches 6-10 feet) for single ornamental use.

Price, (Bush Form), cach, 15c.; soe for 6.

Price, (Tree Form), each, 40c; $\$ 2.20$ for 6 .

\section{Climbing Vines}

\section{Hall's Honeysuckle}

The favorite. Sometimes called Japanese Honeysuckle. Delicate $\mathrm{w}$ h i t e and yellow flowers blooming in June, with some flowers all summer. Heavy pungent fragrance. Dark green foliage holding its full color late into the fall. A vigorous grower, often shooting 7 to 10 feet in a single season.

Price, each, 30e; 80e for 3.

\section{Wisteria}

Chinese Purple. A luxuriant, growing, clinging vine. Beautiful, fine, lacy foliage filled with long, drooping clusters of soft, purple flowers, that come in May. A longlived, hardy vine.

Price, each, 30c; 80. for 3.

\section{Engleman's Ivy}

A new variety. Similar to Boston Ivy but smaller, closer deep green leaves give a softer, more attractive covering. Clings to brick or stone walls and buildings. Kapid grower in dry or wet soil. Deep fall colorings.

Price, each, 35c; 95c for 3.

\section{Clematis Paniculata}

White. The small, white "star" variety that blooms so profusely in late summer. Delicately fragrant. Attractive light green foliage. A hardy grower-one of the most satisfactory flowering vines.

Price, each, 45e; $\$ 1.20$ for 3 .

\section{Clematis Jackmani}

Purple. The most strikingly beautiful clematis. Large, open, deep purple flowers cover the vine in July and August. Deep green, glossy foliage.

Price, each, 750; $\$ 2.00$ for 3 .

\section{Tamarix}

Africana. Distinctive because of its delicate thread-like foliage, dull sea-green in color, waving from long bending branches. Numberless small pink flowers in April before the leaves appear make it a cloud of soft pink. 6 to 10 feet.

Price, 2 to 3 ft., cach, 30c; $\$ 1.55$ for 6.

\section{Excellent Shrubs-Bloomed First Summer \\ Dear sirs :- \\ Staunton, Ill., August 26, 1929. \\ Early this spring I ordered the Rose and Shrub Special from you and wish to compliment you on your excellent stock. Every plant lived and is arowing nicely. The Spirca Van Houtei, Dorothy Perkins and Hydrangea bloomed. I am sending in an order now and hope it is of as excellent stock as the others. \\ Yours truly, \\ (Signed) Mrs. George Hunsinger.}

\section{A Well Pleased Customer}

Gentlemen:-

Flushing, Mich., April, 1929.

We received the first part of our order Saturday, and are very well pleased with our trees and shrubs. This is our first order to Baldwin's, and it will not be our last when in need of nursery stock

(Signed) C. W. Browning.

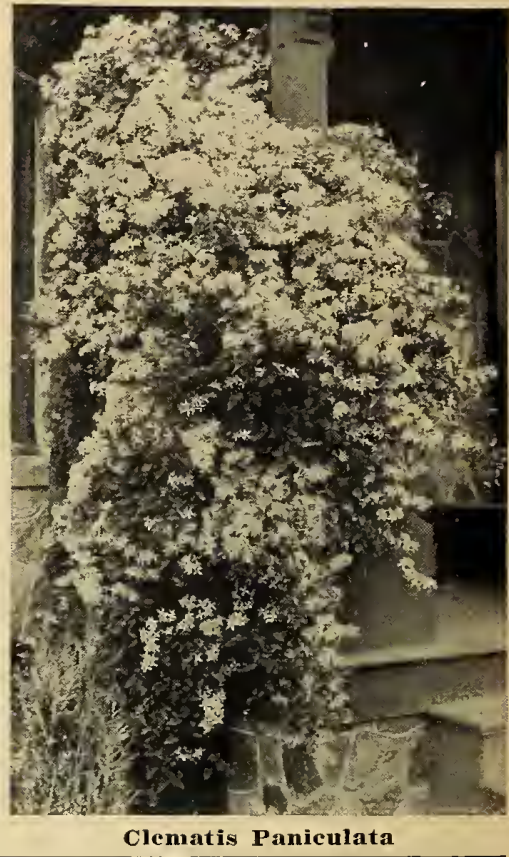




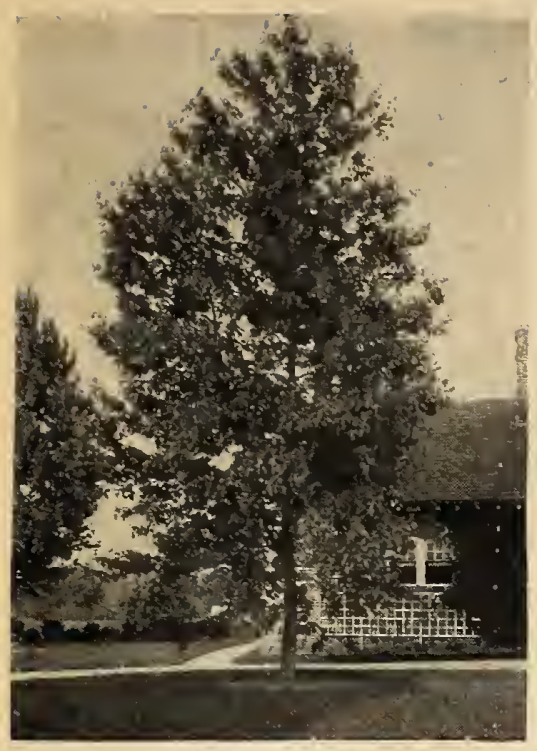

Silver Maple

\section{Weeping Willow}

Spreading, graceful tree with long drooping branches. Long, slender grey-green leavesan imposing tree on any lawn. Grows rapidly on transplanting in wet or dry soils.

\section{Cut-Leaved Weeping Birch}

A distinctive ornamental tree with its white bark, deep cut delicate leaves and graceful, drooping habit. Attractive when planted alone or among others where it stands out strikingly.

\section{How Are You Fixed For Shade Trees?}

Year after year shade trees bring increasing beauty and comfort. Trees frame the landscape and form the backound for all other planting. Our trees are offered in the sizes of each variety best adapted for transplanting. Shade trees promote real estate values.

\section{Silver Maple}

Most desirable because of its quick growth, good foliage and graceful spreading shape. Transplants readily; grows in any good location. Leaves light green, silver underneath-open in early spring and hold late in the fall.

\section{Norway Maple}

Sometimes called European Hard Maple. Similar to our Hard Maple but has larger, darker foliage and a rounder, more spreading growth. Recommended as one of the best shade trees for lawn, park or roadside. Of slower growth than Silver Maple, but of sturdier, heavier form-a distinctive, stately tree.

\section{Schwedler's Red Maple}

The Purple Norway Maple. Resembles Norway Maple closely except that the young leaves are bright purple and red, changing to bronze and then to deep green: changing again in Autumn to brilliant reds and browns. Grows 30 to 50 feet. Thoroughly usable, satisfactory tree-not a novelty.

\section{American Elm}

One of our grandest native trees-“"The Graceful Elm." A strong, vigorous grower great size and unusually long lived. A tree too well known throughout the country to need further description.

\section{Mountain Ash}

Especially desirable for its cheerful yellow and scarlet berries carried from late summer through the winter. Strong grower in wet or dry locations. Small leaves lend appearance of softness to this gracefully branching tree.

\section{Lombardy Poplar}

Rapid growing, spirelike tree reaching a great height. Unsurpassed for screens, narrow lots or background plantings. Plant for quick showing.

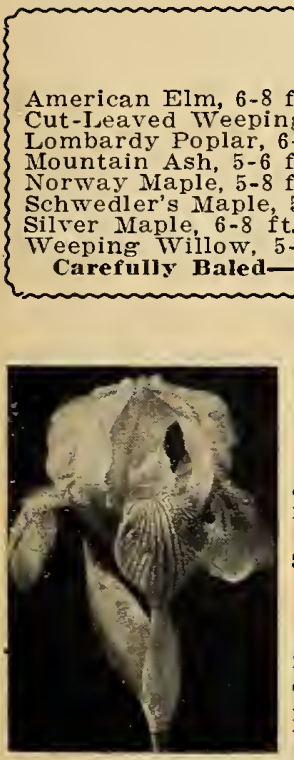

Japanese Iris

\section{Shade Tree Prices}

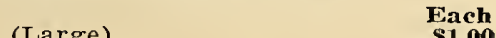

$\$ 1.00$

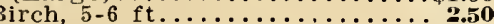

$7 \mathrm{ft} \ldots \ldots \ldots \ldots \ldots \ldots \ldots \ldots \ldots \ldots \ldots \ldots \ldots \ldots . . \ldots \ldots$

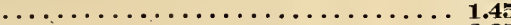

(2.35

ft $\ldots . .2 .35$

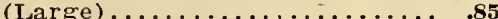

6 ft..............

Only.

\section{Two New Striking Perennials}

\section{You Need Them Both in Your Garden}

\section{Tritoma Pfitzeri}

Red Hot Poker. Unusual and attractive in any garden. Brilliant yellow-red flower spikes extend several feet above green leaves. Blooms July to frost.

Price-POSTPAID IN U. S.-45e each; $\$ 1.20$ for 3 ; $\$ 2.25$ for $6 ; \$ 4.40$ for 12

\section{Japanese Iris}

The newer, most beautiful colored variety of this garden favorite. Present day Japanese Iris ale not to be compared with the "Flags" we used to know. They are a permanent highly prized perennial you wili need in your garden. Selected roots from finest color varieties.

Price-POSTPAID IN U. S.-25e each; 70e for $3 ; \$ 1.25$ for $6 ; \$ 2.25$ for $12 ; \$ 6.50$ for 50 .

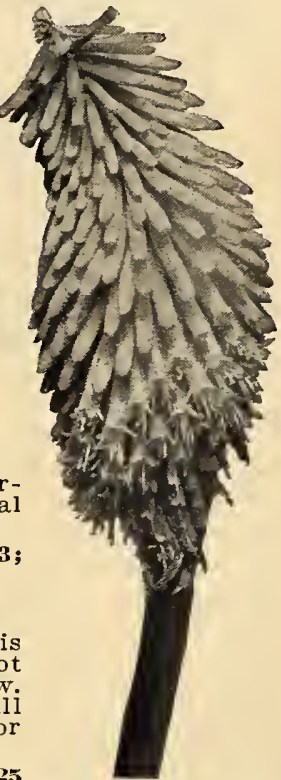

Tritoma Pfitzeri 


\section{Do You Love Roses? Of Course!}

\section{When Mother Nature Made the Rose She Gave Man a Gift of Rarest Beauty}

To the lover of roses-and who is not?-each spring is an opportunity to add more and newer varieties to his collection. Today no garden is complete without several specimens of this - the loveliest of all flowers-the rose. You find a particular satisfaction in growing beautiful roses that you find in growing no other flower. We are offering the best in rose varieties.

\section{Bush Roses}

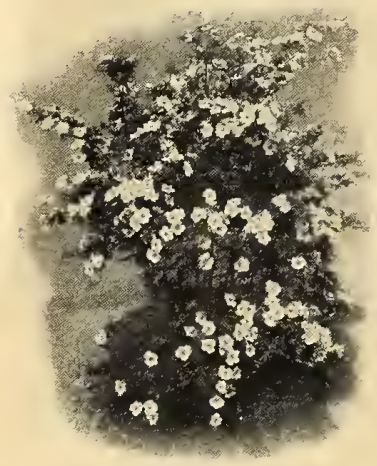

Hugonis "Golden Rose of China"

\section{(Climbing Roses on page 39)}

Frau Karl Druschki-Pure white. A great favorite. The ideal hardy, pure white rose, perfect in form. A strong, rugged grower doing well even under unfavorable conditions. A monthly blooming rose.

Price, each, 45c; $\$ 1.25$ for 3.

Gruss an Teplitz-Deep red. A hybrid tea rose of exquisite loveliness; richest scarlet, shading to velvety crimson; very fragrant; strong grower.

Price, each, $45 \mathrm{c} ; \$ 1.25$ for 3.

Rosa Hugonis-"Golden Rose of China." Genuine Chinese variety-not -a wild rose. A large bush of beautiful, lacy soft green, fern-like foliage, covered in April or early May with a mass of single, clear golden-yellow flowers; borne on long arching sprays. Hardy everywhere.

Price, each, 55c; $\$ 1.45$ for 3.

Los Angeles- Flame pink. The most popular rose next to Radiance.

Chosen one of the "Best Dozen" by rose experts. Extremely beautiful in both bud and flower. Delicately shaded flame pink, apricot and gold.

\section{Price, each, 55c; $\$ 1.45$ for 3.}

Mme. Butterfly-Pink. A newer rose of real merit. Exquisite delicate pink shading to soft gold at the base. Fine for cutting; a steady bloomer-good in the fall.

Price, each, 55c; $\$ 1.45$ for 3.

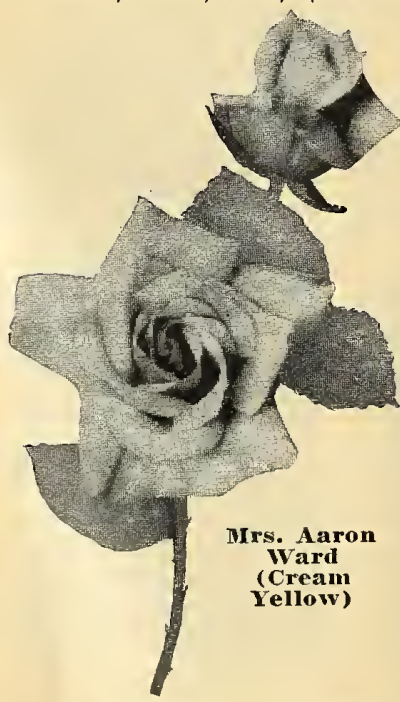

Mrs. Aaron Ward-Cream yellow. One of the finest and most beautiful of yellow roses. Continuously blooming. Buds are a rich golden fawn and on opening quickly change to soft pink and cream. We want you to have at least one bush in your garden.

Price, each, 55c; $\$ 1.45$ for 3.

Paul Neyron-True rose pink. Immense globe-like flowers on long, stout stems. Bush hardy, vigorous and comparatively free from thorns. Add it to your rose garden.

Price, each, 45c; $\$ 1.25$ for 3 .

Red Radiance-Cerise red. Probably the best known and most popular of the lighter red shades. Big round blooms of cerise red. Hardy, vigorous. Price, each, 45c; \$1.25 for 3.

Souv, de Claudius Pernet-Lem on yellow-Another new rose. Just what rose lovers have been looking for - a clear brilliant yellow-and what is more, one that does not fade. Exceptionally fine for cutting. Does best in hot, dry weather.

Price, each, 55e; $\$ 1.45$ for 3.

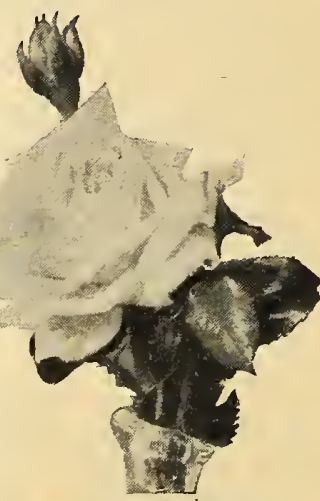

Souv, de C. Pernet (Lemon Yellow)

"How to Grow Roses"

by Pyle, MeFarland \& Stevens

Makes every step in the culture and care of roses so clear that an $y$ grower can succeed. America's $\mathrm{m}$ ost popular rose book completely rewritten. 144 pages, 32 plates in full color, 32 half-tones. Price, postpaid, $\$ 2.20$. 



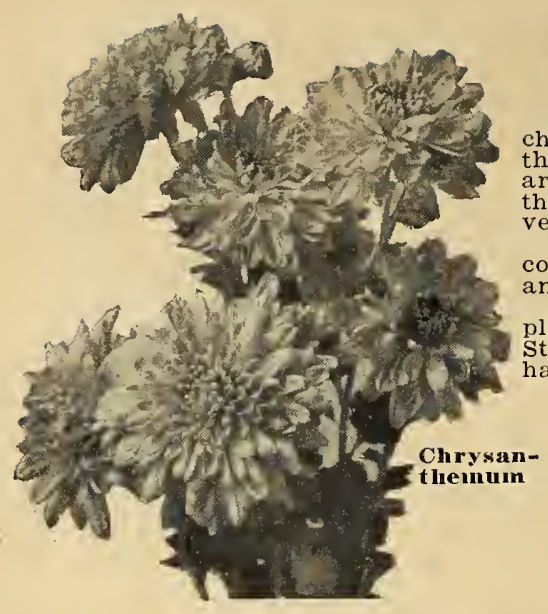

Hardy Phlox

July-Septembcr. These beautiful hardy border plants are among the most effective things in the garden in late summer and fall. These newer varieties, much improved both in color and size of bloom, offer a wide range of rich colors.

Bridesmaid. Excellent pure white; red eye. Eelaireur. Best real red phlox we have.

Ferdiuaud Cortez. Red, deep rose pink.

Mrs. Charles Dorr. Unusual lilac purple.

Rhinestrom. Large pink.

R. P. Struthers. Deep salmon; one of the best.

\section{Other Hardy Perennials}

Aquilegia-Columbine. May-July. One of the daintiest outdoor grown flowers. Does well anywhere, though preferring a moist, sunny spot. A most important part of every old-fashioned garden.

Campanula-Canterbury Bell. May-June. (See illustration.) Another old favorite; covered with large bell-shaped flowers on long stems. Showy in mixed borders.

Chrysantlenum. Sept.-Nov. (See illustration.) Every one knows these brilliant, hardy flowers. They extend garden colors up to winter. Nothing better for cutting.

Coreopsis-Tick Seed. June-October. One of the best hardy plants: golden yellow flowers, daisy-like, but broader petals, w ith notched edges.

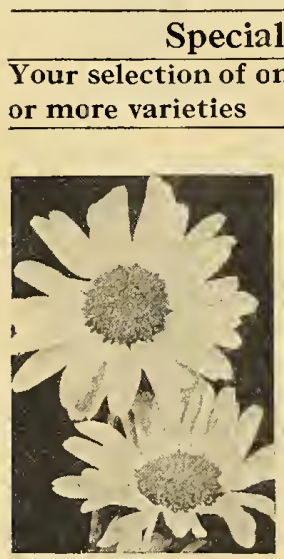

Shasta Daisy

\section{Hardy Perennial Flowers}

The Finishing Touch to Yard and Garden

very home needs a flower garden! Hardy flowers bring and fragrance to the garden, to the doorstep and to etable garden and in a garden by themselves.

rdy Perennials are a pleasure to the home gardener need of seeding or planting every spring.

ur list offers Perennials that are best adapted to transting and will give you flowers all summer long. at least six to make a showing. frost (See illus.) Queen of the gardenbeautiful shades of blue and lavender flowers borne on tall spikes add a distinction to the perennial bed that no other flowers give.

Dianthus-Hardy Pinks. May-June. Without the spicy fragrance of hardy pinks a garden is incomplete. Their perfect form and rich coloring make them great favorites for edging flower beds and garden walks.

Digitalis-Foxglove. June-July. Old-fashioned, dignified and stately. Rich green masses of leaves always attractive and when in bloom this plant dominates the garden.

Gaillardia-BIanket Flower. June to frost. Vigorous grower in all soils. Quantities of fine blooms deep yellow shaded to rich brown and red at the centers. Good cut flower.

Hollyhocks. June-July. One of the most stately, picturesque and beautiful plants in the world. There is always room for this old garden favorite. Pink and red, double and single blooms.

Lupines. July-August. There are but few good blue flowers-this is one. Beautiful, foot long spikes of pea shaped flowers on three foot stems. Plant in moist location.

Physalis-Chinese Lantern Plant. August to frost. Its bright orange-scarlet lantern like fruits make decorative, cheerful winter bouquets. Very attractive garden plant.

Pyreth rum-Painted" $\mathbf{D}$ a is $\mathbf{y}$. May-July. Ideal cut flowers: blooms uninjured by wind and sun. Perfectly hardy, grows everywhere. Mixed colors.

Shasta Daisy. June-August. (See illus.) Bright and sturdy, well known garden daisy. Large clear white petals, yellow centers.

Sweet William. April-May. An old-fashioned favorite; spice-scented; flowers like pinks but borne in clusters; fine for cut. ting. Colors variegated.

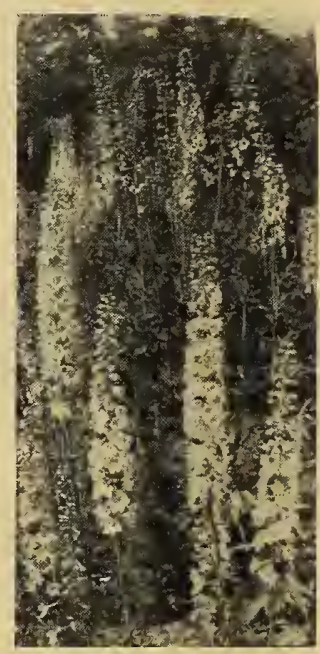

Delphinium 


\section{BALDWIN'S 1930 PRICES}

Will Save You Money-Compare Prices And See For Yourself

IMPORTANT NOTE: On Parcel Post Orders send just actual price of plants. No need to figure postagewe will ship C.O.D. for exact postal charges-you pay the postman. Quicker delivery and your stock is insured.

PRICES NOT PREPAID-AII F.O.B. Bridgman.

500 or more of a variety at 1000 rates; less quantities of each variety at prices listed below. Evergreens, Page 29; Shade Trees, Page 31 ; Hardy Perennials, Pages 31,33

\section{SPECIAL DISCOUNT FOR EARLY ORDERS TO BALDWIN CUSTOMERS}

10\% Cash Discount-On All Orders Received Before February 10th 5\% Cash Discount-On All Orders Received Between Feb. 10th and March 10th

NOTE: All or part cash must be enclosed with every order. Discount does not apply on special collection offers in this catalog. but does apply to prices listed on this and the following page.

\begin{tabular}{|c|c|c|c|c|c|c|c|c|c|c|c|c|}
\hline Page. & \multicolumn{3}{|l|}{ STRAWRERRIES } & $\begin{array}{c}\text { Per } \\
12\end{array}$ & $\begin{array}{l}\text { Per } \\
25\end{array}$ & $\begin{array}{l}\text { Per } \\
\text { 50 }\end{array}$ & $\begin{array}{c}\text { Per } \\
75\end{array}$ & $\begin{array}{l}\text { er } \\
00\end{array}$ & 200 & $\begin{array}{l}\text { Per } \\
300\end{array}$ & $\begin{array}{l}\text { Per } \\
400\end{array}$ & $\begin{array}{c}\text { Per } \\
1000\end{array}$ \\
\hline & \multirow{2}{*}{\multicolumn{3}{|c|}{ 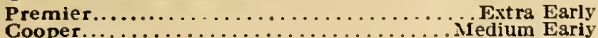 }} & & .40 & .70 & 0.90 & 1.10 & & & & \\
\hline & & & & & & & 1.05 & & & & & \\
\hline & \multicolumn{3}{|c|}{ 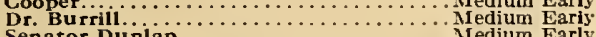 } & & . & & & & & & & \\
\hline 3 & \multirow{2}{*}{\multicolumn{3}{|c|}{ Gibson............................... }} & & & & & & & & & \\
\hline 8 & & & & & & & & & & & & \\
\hline & \multirow{2}{*}{\multicolumn{3}{|c|}{$\begin{array}{l}\text { Booster } \ldots \ldots \ldots \\
\text { Aroma. }\end{array}$}} & &. & .80 & 1.05 & 1.40 & & & & 5.5 \\
\hline & \multicolumn{2}{|c|}{ Aroma } & & &. .35 & $\begin{array}{r}.60 \\
1.05\end{array}$ & $\begin{array}{r}.8 \theta \\
1.40\end{array}$ & $\begin{array}{r}.95 \\
1.80\end{array}$ & $\begin{array}{l}1.50 \\
2.75\end{array}$ & & $\begin{array}{r}2.50 \\
4.50\end{array}$ & 10.5 \\
\hline 11 & Pearl... & & & & .45 & & .05 & 1.40 & & & & \\
\hline 3 & \multirow{2}{*}{\multicolumn{3}{|c|}{ 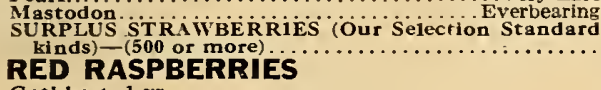 }} & $\$ 0.50$ & .90 & 1.75 & 2.25 & 2.45 & 4.90 & & 7.70 & 17. \\
\hline 18 & \multirow{2}{*}{\multicolumn{3}{|c|}{ 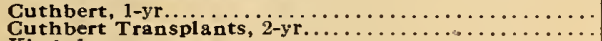 }} & .40 & .75 & 1.35 & 1.85 & 25 & 3.70 & & 6.40 & \\
\hline 1 & & & & & 1.30 & & & & & & 10.75 & \\
\hline 1. & \multirow{2}{*}{\multicolumn{3}{|c|}{ 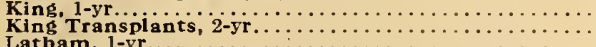 }} & .40 & .75 & 1.35 & 1. & & 3.70 & & 6.40 & \\
\hline 1 & & & & .70 & 1.30 & 2.20 & & 3.75 & 6.00 & & 10.75 & \\
\hline $\begin{array}{l}18 \\
13\end{array}$ & \multirow{2}{*}{\multicolumn{3}{|c|}{ Latham, Transpiants, $2-y \mathrm{r}$}} & .65 & 1.20 & 2.10 & 2.75 & 3.65 & 5.75 & 8.25 & 10.40 & 24. \\
\hline 14 & & & & $\begin{array}{r}1.35 \\
.50\end{array}$ & $\begin{array}{r}2.40 \\
.90\end{array}$ & $\begin{array}{l}3.95 \\
1.70\end{array}$ & $\begin{array}{l}5.50 \\
2.20\end{array}$ & $\begin{array}{l}6.85 \\
2.60\end{array}$ & $\begin{array}{r}11.80 \\
4.25\end{array}$ & $\begin{array}{r}1.75 \\
5.75\end{array}$ & $\begin{array}{r}19.80 \\
7.30\end{array}$ & $\begin{array}{l}45.0 \\
16.0\end{array}$ \\
\hline 14 & \multicolumn{3}{|l|}{ St. Regis Transplants, $2-y r$. } & 1.00 & 1.70 & 3.00 & 3.90 & 4.70 & 7.50 & $\begin{array}{r}10.50 \\
5.75\end{array}$ & 13.20 & 30.0 \\
\hline 4 & \multicolumn{3}{|l|}{$\begin{array}{l}\text { Victory Transplants, } 2 \text {-yr...... } \\
\text { BLACK RASPBERRIES }\end{array}$} & .80 & 1.50 & 2.70 & $\begin{array}{l}2.20 \\
3.70\end{array}$ & $\begin{array}{l}2.60 \\
4.50\end{array}$ & $\begin{array}{l}4.20 \\
7.40\end{array}$ & 10.20 & 12.80 & 28.0 \\
\hline 15 & \multicolumn{3}{|l|}{$\begin{array}{l}\text { Cumberland Tips, } 1-\mathrm{yr} . \ldots \\
\text { Cumberland Transplants, } 2 \text {-yr. }\end{array}$} & .60 & .95 & $\frac{1.85}{3.50}$ & & & 4.75 & 6.60 & 8.00 & 18.0 \\
\hline 16 & \multirow{2}{*}{\multicolumn{3}{|c|}{$\begin{array}{l}\text { Honeysweet Tips, } \\
\text { Kansas Tips, 1-yr.. }\end{array}$}} & $\begin{array}{r}1.20 \\
.70\end{array}$ & 1.30 & 2.2 & 2.9 & 3.75 & 6.00 & 8.50 & 10.75 & 25 \\
\hline 16 & & & & .60 & .95 & 1.85 & 2. & & & & 8.00 & \\
\hline 10 & \multicolumn{3}{|c|}{$\begin{array}{l}\text { Plum Farmers Tips, } 1-\text { yr } \text { BLW DEWBERRIES } \\
\text { BLACBERRIES AND DE }\end{array}$} & & .95 & 1.8 & 2 & 2.95 & 4.75 & & 8.00 & 18. \\
\hline 17 & \multirow{5}{*}{\multicolumn{3}{|c|}{ 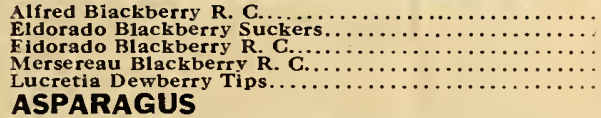 }} & 1.15 & 1.85 & S. & 4.4 & & & & & \\
\hline 17 & & & & .50 & .90 & 1. & & & 4.25 & & $\begin{array}{r}7.45 \\
8.80\end{array}$ & 20 \\
\hline 18 & & & & & 1. & & & & 5.50 & & 8.80 & \\
\hline 18 & & & & & .80 & 1.5 & 1. & 2. & 3.90 & 5. & 6.90 & 15 \\
\hline & & & & & & & & & & & & \\
\hline & \multicolumn{3}{|l|}{$\begin{array}{l}\text { Martha Washington, 1-yr., No. } 1 . \\
\text { Martha Washington, } 2 \text {-yr., No. } 1 .\end{array}$} & .2 & .40 & 1.70 & 1.9 & 1. & 3. 1 & 4.2 & $\begin{array}{l}3.50 \\
\mathbf{5 . 2 5}\end{array}$ & 12 \\
\hline \multirow{2}{*}{ Page } & \multirow{3}{*}{$\begin{array}{l}\text { RHUBARB } \\
\text { Myatt's Vlctoria, 2-yr., Large } \ldots \ldots \ldots \ldots \\
\text { GRAPE VINES }\end{array}$} & & $\overline{\text { er }}$ & & & & Per & & Per & & & \\
\hline & & & & & & & & & & & & \\
\hline 18 & & $\$ 0.07$ & $\$ 0.40$ & $\$ 0.70$ & $\$ 1.30$ & $\$ 2.20$ & $\$ 3.00$ & $\$ 3.85$ & $\$ 6.40$ & $\$ 8.80$ & $\$ 11.00$ & $\$ 26$. \\
\hline 19 & & & & & & & & & & & & \\
\hline 30 & & .0 & & & & & & & 5.75 & & & $2 \dot{4}$ \\
\hline & & & & & & & & & & & & \\
\hline & & & & & & & & & & & & \\
\hline & & & & & & & & & & & & \\
\hline & & & & & & & & & & & & \\
\hline & & & & & & & & & & & & \\
\hline & & & & & & & & & & & & \\
\hline & & & & & & & & & & & & \\
\hline & & .1 & & & & 4.50 & 0.10 & & & & & \\
\hline & 5 & .1 & .80 & & & 4.85 & 6.85 & 8.50 & & & & \\
\hline
\end{tabular}

\begin{tabular}{|c|c|c|c|c|c|c|c|}
\hline APPLES $2-\mathrm{yr}_{30} 5$ to $6 \mathrm{ft}$. & Each & $\begin{array}{c}\text { Per } \\
10\end{array}$ & $\begin{array}{l}\text { Per } \\
100\end{array}$ & \multirow{2}{*}{ 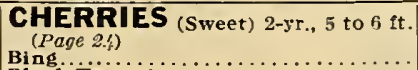 } & Each & Per & $\begin{array}{l}\text { Per } \\
100\end{array}$ \\
\hline $21-20,40)$ & $\$ 0.35$ & $\$ 3.25$ & $\overline{\$ 30.00}$ & & $\$ 0.60$ & $\$ 5.50$ & $\$ 50.00$ \\
\hline & & 3.25 & 30.00 & Black Tartarian & & & \\
\hline & .35 & 3.25 & 30.00 & Napoleon....... & .60 & 5.50 & 50.00 \\
\hline & .35 & 3.25 & 30.00 & Windsor............. & & & \\
\hline & .35 & 3.25 & 30.00 & PEACHES & & & \\
\hline sa & .35 & 3.25 & 30.00 & 40) & & 2.75 & \\
\hline 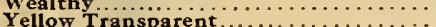 & .35 & 3.25 & 30.00 & & .30 & 2.75 & \\
\hline & .35 & 3.25 & 30.00 & & .30 & 2.75 & \\
\hline PEARS 2-yr., 5 to $6 \mathrm{ft}$. (Page 23 ) & & & & & & $\begin{array}{l}2.75 \\
2.75\end{array}$ & 25.00 \\
\hline Anjou... & .50 & $\begin{array}{l}4.75 \\
4.75\end{array}$ & 45.00 & & & 2.75 & 25.00 \\
\hline rite & .50 & $\begin{array}{l}4.75 \\
4.75\end{array}$ & $\begin{array}{l}45.00 \\
45.00\end{array}$ & & & 2.75 & $\begin{array}{l}25.00 \\
35.0\end{array}$ \\
\hline & .50 & $\begin{array}{l}4.75 \\
4.75\end{array}$ & $\begin{array}{l}45.00 \\
45.00\end{array}$ & & .40 & & \\
\hline & .50 & 4.75 & 45.00 & it. & & & \\
\hline DES (Sour) $2-\mathrm{yr}, 5$ to $6 \mathrm{ft}^{\circ}$ & & & & ae. & 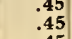 & $\begin{array}{l}4.25 \\
4.25\end{array}$ & 40. \\
\hline Earl &. $\mathbf{4 5}$ & $\begin{array}{l}4.25 \\
4.75\end{array}$ & $\begin{array}{r}40.00 \\
45.00\end{array}$ & & $\begin{array}{r}.45 \\
.45\end{array}$ & $\begin{array}{l}4.25 \\
4.25\end{array}$ & $\begin{array}{r}40.00 \\
40.00\end{array}$ \\
\hline
\end{tabular}




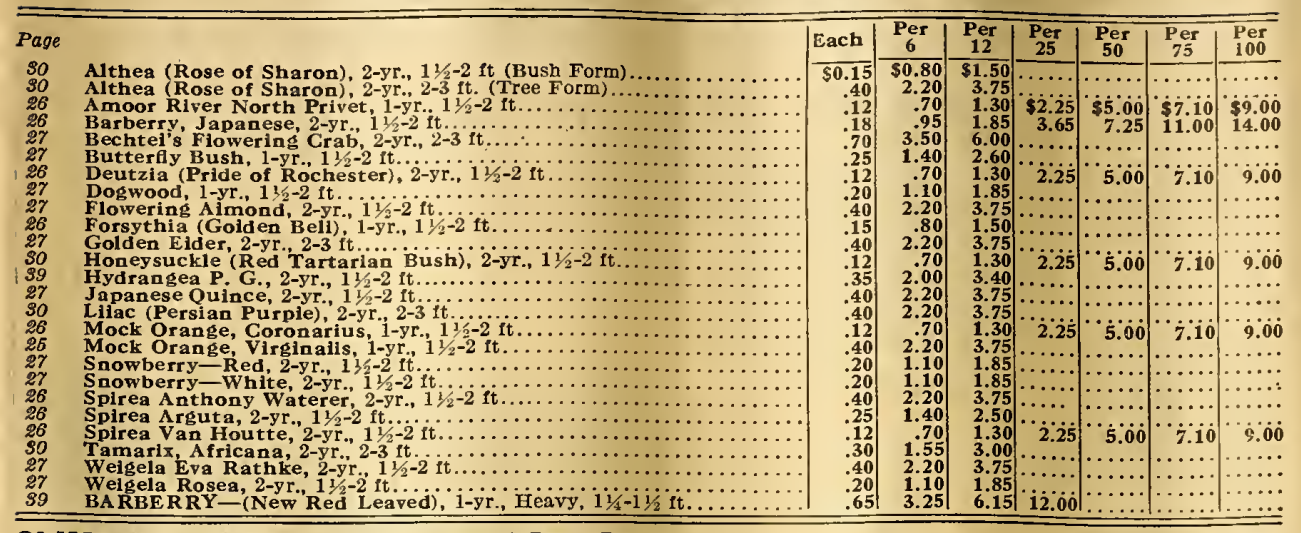

\begin{tabular}{|c|c|c|c|c|c|c|c|}
\hline CLIMBANG MINES 2-yr., No. 1 & Each & $\operatorname{Per}_{3}$ & $\underset{6}{\operatorname{Per}}$ & \multirow{4}{*}{ 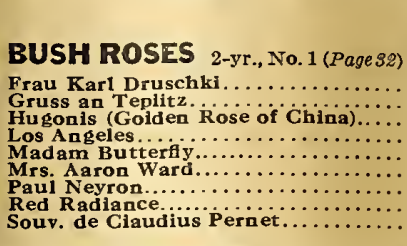 } & Each & $\underset{3}{\text { Per }}$ & $\begin{array}{c}\text { Per } \\
10\end{array}$ \\
\hline lematis Jackm & $\$ 0.75$ & $\$ 2.00$ & $\overline{\$ 3.50}$ & & & & \\
\hline $\begin{array}{l}\text { Clematis Paniculat } \\
\text { Engleman's Ivy.... } \\
\text { Hall's Honeysucikie. } \\
\text { Wisteria, Chinese P } \\
\text { CLIB BN RO }\end{array}$ & $\begin{array}{r}.45 \\
.35 \\
.30 \\
.30 \\
\text { Each }\end{array}$ & $\begin{array}{r}1.20 \\
.95 \\
.80 \\
.80 \\
\text { Per }\end{array}$ & $\begin{array}{l}2.25 \\
1.75 \\
1.50 \\
1.50 \\
\text { Per } \\
10\end{array}$ & & \multirow{2}{*}{$\begin{array}{r}\$ 0.45 \\
.45 \\
.55 \\
.55 \\
.55 \\
.55 \\
.45 \\
.45 \\
.55\end{array}$} & \multirow{2}{*}{$\begin{array}{r}\$ 1.25 \\
1.25 \\
1.45 \\
1.45 \\
1.45 \\
1.45 \\
1.25 \\
1.25 \\
1.45\end{array}$} & \multirow{2}{*}{$\begin{array}{r}\$ 3.75 \\
3.75 \\
4.50 \\
4.50 \\
4.50 \\
4.50 \\
3.75 \\
3.75 \\
4.50\end{array}$} \\
\hline $\begin{array}{l}\text { Grimson Ramble } \\
\text { Dorothy Perkins. } \\
\text { Gardenia........ } \\
\text { Paul's Scariet... }\end{array}$ & $\begin{array}{r}\$ 0.35 \\
.30 \\
.50 \\
.35 \\
\end{array}$ & $\begin{array}{r}\$ 0.95 \\
.80 \\
1.35 \\
.95 \\
\end{array}$ & $\begin{array}{r}\$ 3.00 \\
2.50 \\
4.00 \\
3.00 \\
\end{array}$ & & & & \\
\hline
\end{tabular}

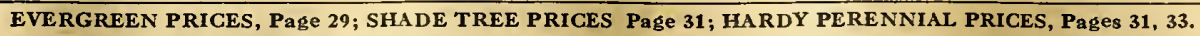

SPECIAL PRICED OFFERS ON COLLECTIONS OF ALL KINDS, also Dahlias \& Glads., Pages 37-38.

\section{Instructions for Ordering-Please Read Carefully}

\section{Parcel Post Shipments}

Everything except trees can be sent by mail. Quick delivery right to your door in city or country. Express is sometimes cheaper on larger orders. We can probably tell the best and cheapest way to ship your larger orders. If you care to leave it to us, just check "Our judgment" on the order blank. On all small and average sized orders, mail shipment is cheaper and better for you.

\section{Send No Money For Postage-Mail Shipments Sent C. O. D. For Charges}

You pay the postman. This is the cheaper way for you, because it is impossible to estimate just what your plants will weigh. Postal clerks give C. O. D. shipments preference, assuring more prompt delivery. Another thing-C. O. D. shipments are automatically inof plants only, and we will send them C. O. D. for the exact postage.

LOCATION: Bridgman, Berrien County, Southwestern Michigan-the heart of the "Michigan Fruit Belt." Fast service to Chicago trunk lines east, west, north, south.

EXPRESS SHIPMEN'TS: Cheapest for large orders. Rapid handling. Charges not prepaid.

SHIPPING SEASONS-SPRING: From last of March or first of April to May 15th to 25th, according to season. FALL: October 10th to November 15 th.

PACKING: No charge. All plants packed in damp moss or shingle tow. Will keep in good condition 5 days to 2 weeks, according to time of shipment and weather conditions. Each variety carefully separated in package and correctly labeled.

SUBSTTTUTMON: No substitution without your permission, except on late orders when time is often saved by substituting varieties of same season and value as those ordered. We guarantee satisfaction on varieties substituted.

ORDER EARLY: The earlier you order the surer you will be of getting the varieties you want. Many varieties sell out quickly. Order now, we will reserve yours.

HOW TO ORDER: Write your name and address plainly on enclosed order blank. Indicate "Mail," "Express," or "Our judgment," as you prefer. If express shipment, be sure there is an express office at the destination you give. Enclose remittance. Your order acknowledged promptly.

PRICES: See above. Also Evergreens, page 29; Shade Trees, page 31 ; Perennials, pages 31,33 .

TERIIS: Orders of $\$ 5.00$ or less, please send cash with order; if more than $\$ 5.00$, please remit $25 \%$ of total amount with order, balance before shipment. No credit or C. O. D. shipments.

REMITTANCES: Send check, Bank Draft, Express Money Order, or P. O. Money Order. If you send Currency, register your letter.

REFERENCES: Our local Express Agent or Postmaster; also Bridgman State Bank of Bridgman, or the Commercial National Bank, St. Joseph, Mich.

COMPLAINTS: All complaints as to condition on arrival, shortage or errors must be made within five days after stock is received. This allows ample time to examine shipments, and if there is anything wrong, the sooner we know it, the sooner it can be satisfactorily adjusted. That is just exactly what you want. Out of thousands of shipments we make few errors. Complaints as to condition on arrival must be accompanied by express or postoffice receipt showing statement of bad condition. 


\section{ORDER SHEET O.A.D. Baldwin Nursery Co., Bridgman, Mich.}

\begin{tabular}{|lr|}
\hline \multicolumn{2}{|c|}{ DO NOT WRITE HERE } \\
\hline Total Am't. \$ & \\
\hline & C.K. \\
\hline Am't Rec'd \$ & C.A. \\
\hline Balance Due \$ & S.T. \\
\hline Parcel Post Zone \\
\hline
\end{tabular}

\begin{tabular}{|l|l|}
\hline \multicolumn{2}{|c|}{ PLEASE FILL OUT BELOW } \\
\hline \begin{tabular}{c|l} 
Ship \\
By
\end{tabular} & $\frac{\text { Mail }}{\text { Express }}$ \\
\hline Am't Enclosed, \$ \\
\hline Ship About \\
\hline (Shipping Date) \\
\hline
\end{tabular}

\section{Name}

R. F. D. or Street

\section{Postoffice}

State

\section{Town to Ship Express to}

\begin{tabular}{l|l|l|l}
\hline \hline HOW \\
MANY
\end{tabular}

You Don't Need to Include.Postage on Mail Shipments

We Will Ship C.O.D. for Exact Amount of Postage-See Page 35 This also speeds up delivery and insures your stock against loss or damage. 

Save You Time and Money ing Now?-Select What You Want

ract something of erersthing Is included In these offers. We make
, to become better acquainted with our constinnty incrensing selec.

Lave just what you need to make a complete planting for your

- rder Today and Be Sure of These Savings

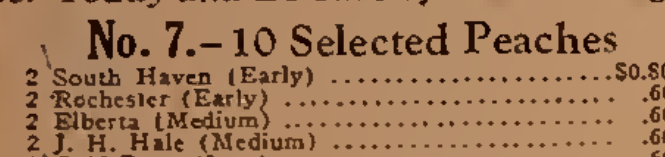

No. 12.-Hedge Shrub Bargains

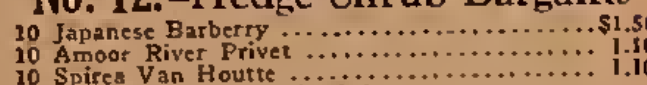
(All $11 / 2$ to 2 st sbrubs)

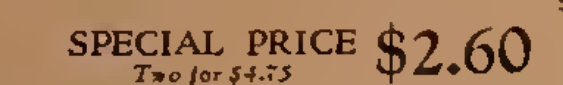
I No. 8.-4 Selected Pears

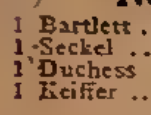

No.13.ShrubFoundation Planting

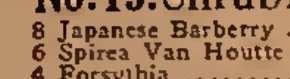

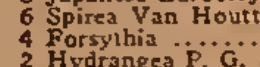

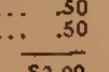
$\underset{T * \text { for } 52.95}{\text { SPECICE }} \$ 1.60$ No.9.-5 Selected Cherries

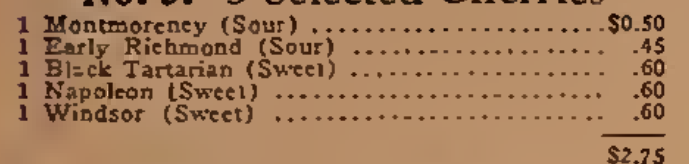

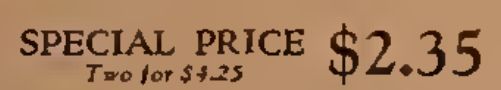

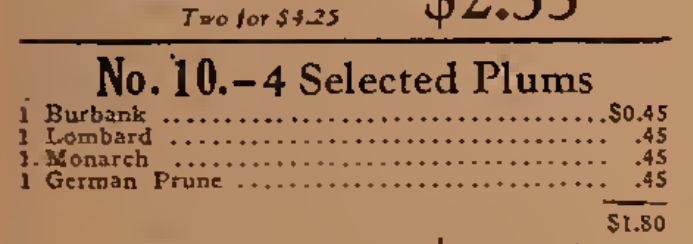

$\underset{\text { Tro for } \$ 2.60}{\text { SPECICE }} \$ 1.45$

No. 11.-Complete Home Orchard

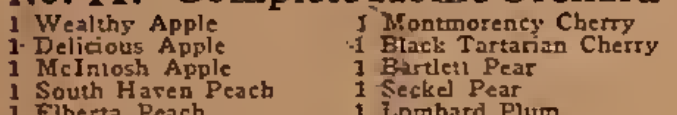

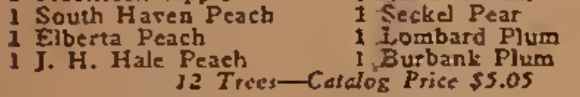

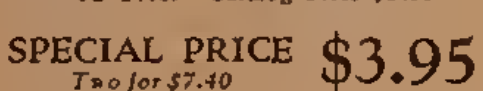

$$
\underset{\text { SPE for } \$+.65}{\text { SPICE }} \$ 2.60^{\$ 3.60}
$$

No.14.CompleteLandscapeGroup

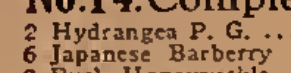

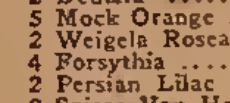

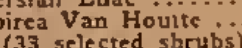

SPECIAL PRICE $\$ 3.95^{\frac{.87}{\text { Ss.40 }}}$

No.15.-5 Bush Roses Selected Strong 2 .r. Bushes
Our Selcction of choice Varietices. SPECIAL PRICE $\$ 1.95$

No. 16. 5 Selected Shade Trees

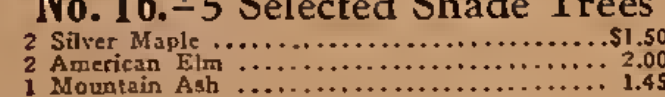
$\underset{T: s 0 \text { for } \$ 7.45}{\text { SPECIAL PRICE }} \$ 3.95^{\text {S4. }}$

Just Order These Collections By Number

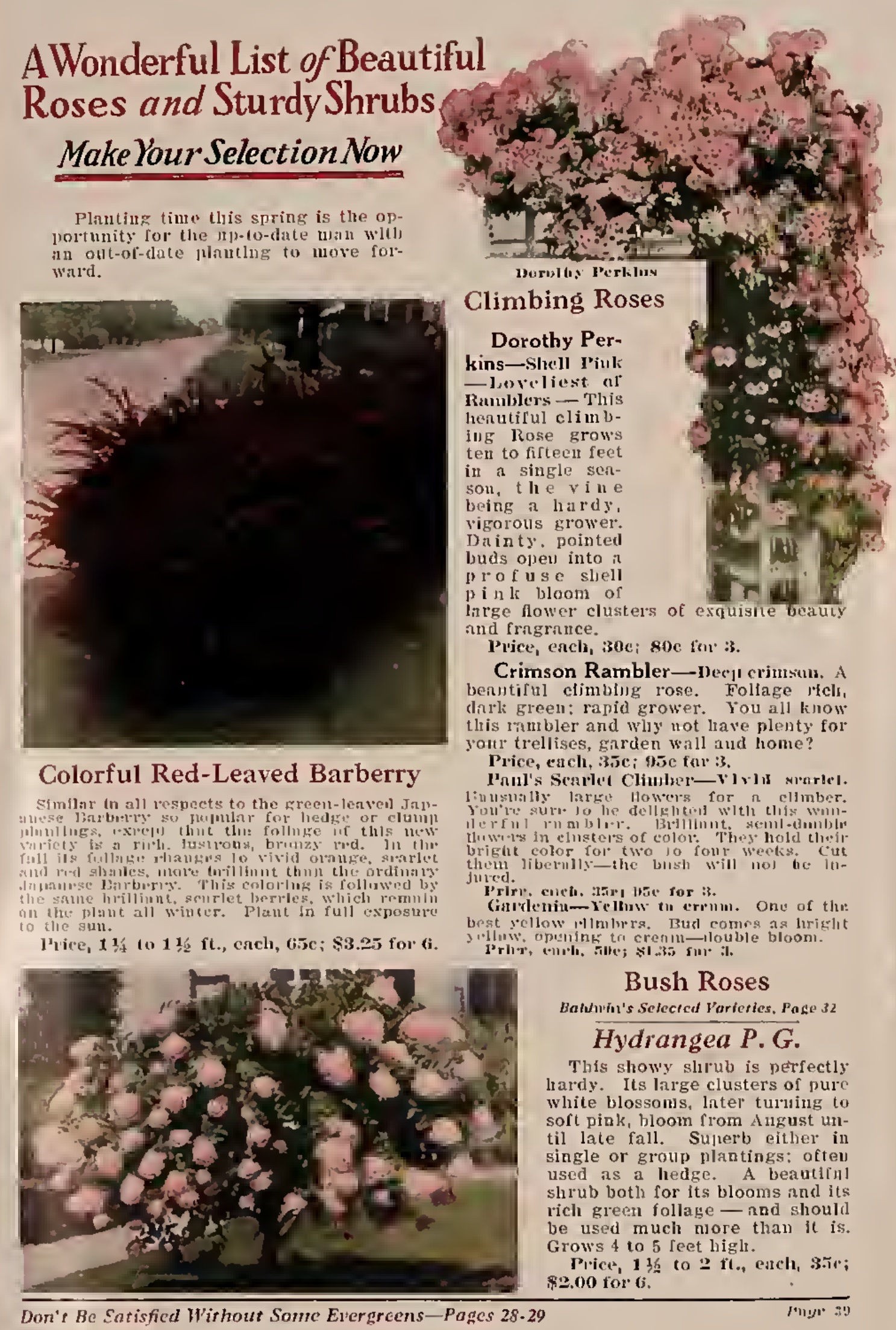

Sour Cherries

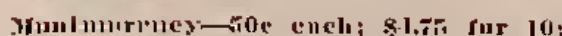

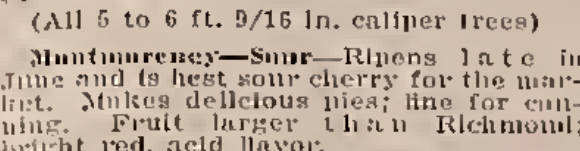

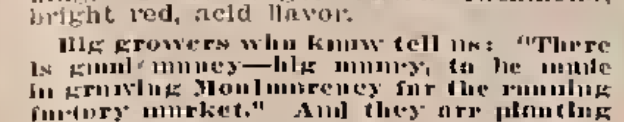

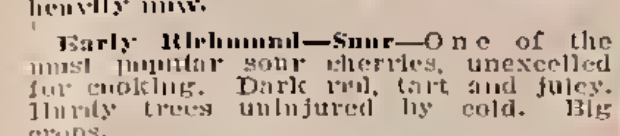

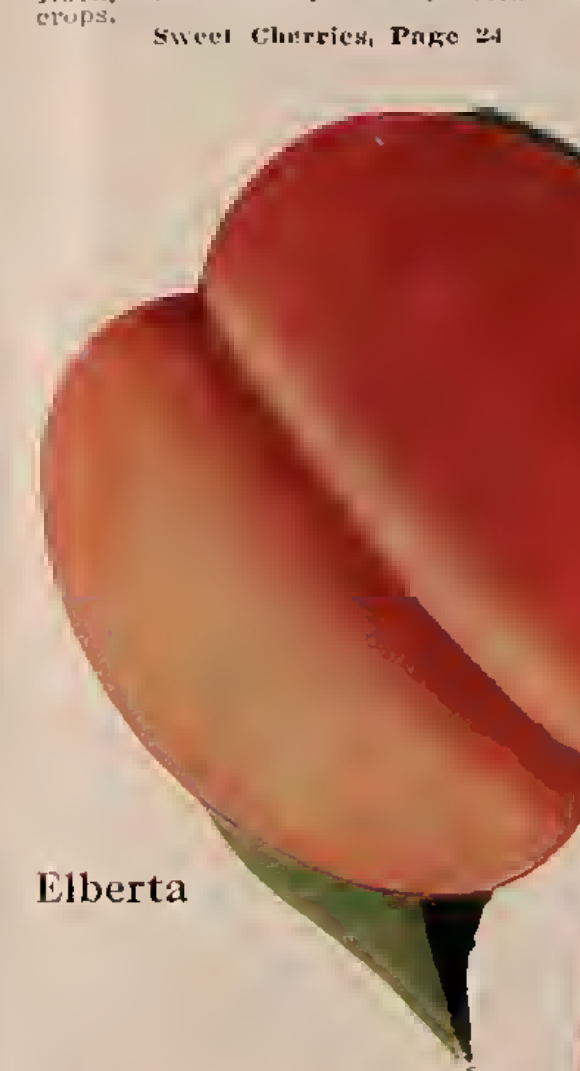

Apples $\underset{\substack{35 \text { Cents } \\ \text { Each }}}{2}$

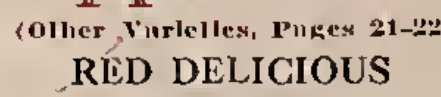
RED DELICIOUS
Known the World Oicr Krown the World O'cr
Winter. Brilliant dark red,
slialint to yellow at blossoum ndi. Lirge to very large: white
ender juicy flesh. wourderrully ricls sub-acld flavor-truly dell
cious. Ships without bruising:
makes a wonderful appearance

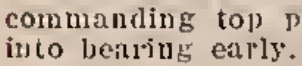

Page 5 Has a Complete Index.
frinted in U.S. A.
The Famous Montmorency

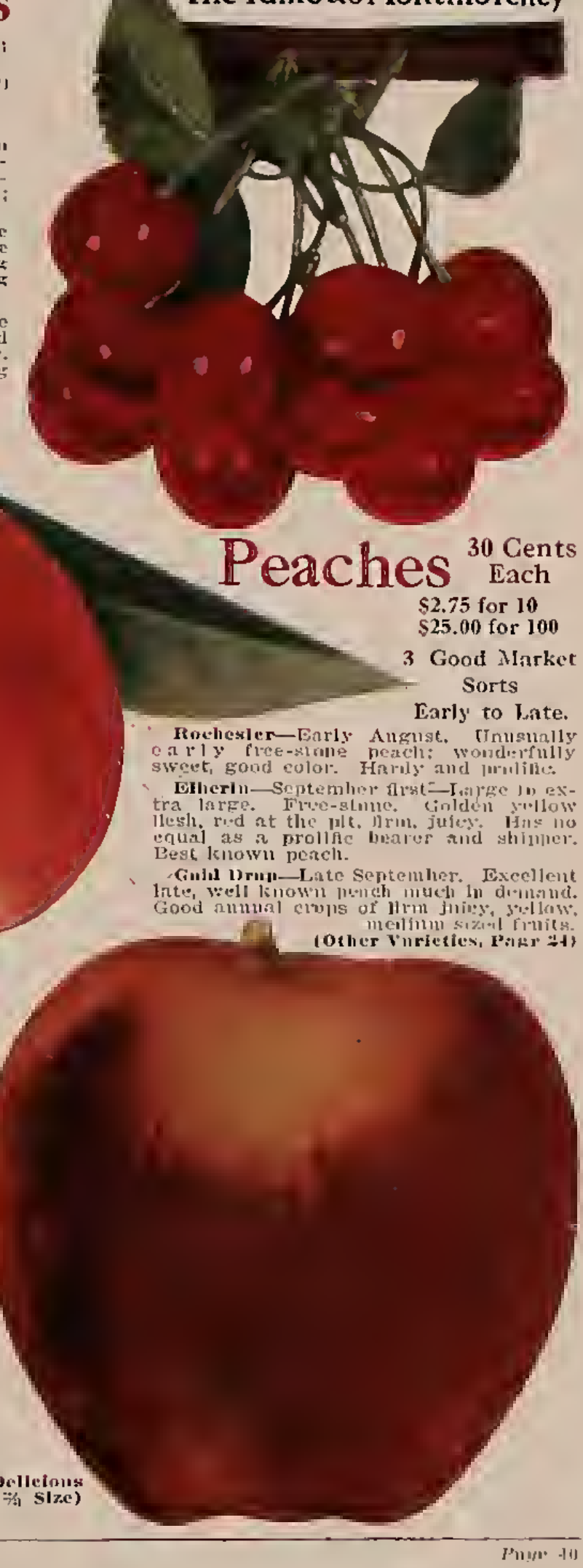




\section{AWonderful List of Beautiful}

Roses and Sturdy Shrubs

\section{MakeYour Selection Now}

Planting time this spring is the opportunity for the up-to-date man with an out-of-date planting to move forward.

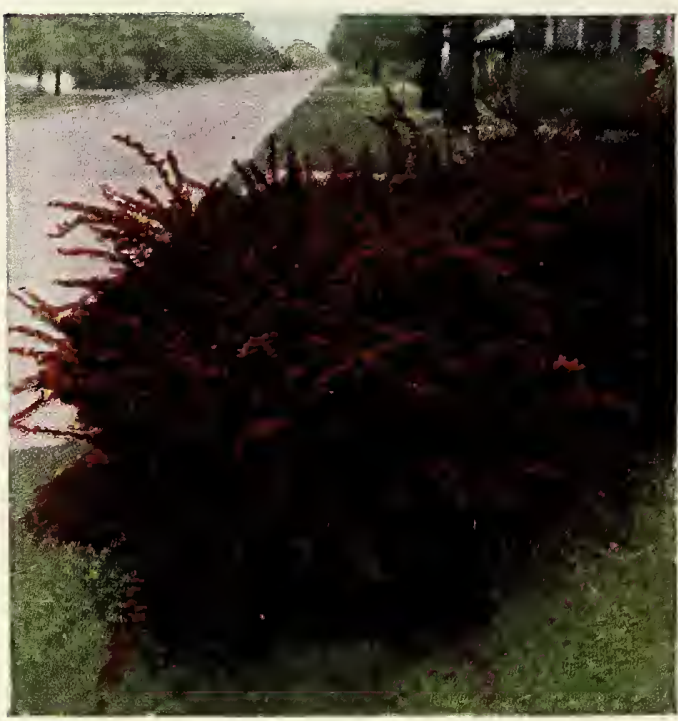

\section{Colorful Red-Leaved Barberry}

Similar in all respects to the green-leaved Japanese Barberry so popular for hedge or clump plantings, except that the follage of this new variety is a rich, lustrous, bronzy red. In the fall its foliage changes to vivid orange, scarlet and red shades, more brilliant than the ordinary Japanese Barberry. This coloring is followed by the same brilliant, scarlet berries, which remain on the plant all winter. Plant in full exposure to the sun.

Price, $1 \frac{1 / 4}{4}$ 10 1 1/2 ft., each, $65 \mathrm{c} ; \$ 3.25$ for 6.

\section{0} 1

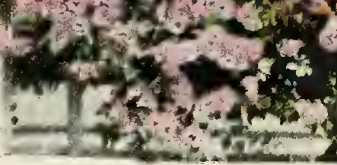

Climbing Roses

\section{Dorothy Per-} kins-Shell Pink - Loveliest of Ramblers - This beautiful climbing Rose grows ten to fifteen feet in a single season, $t h$ e vine being a hardy, vigorous grower. Dainty, pointed buds open into a p r of u se shell p i n k bloom of large flower clusters of exquisite beauty and fragrance.

Price, each, 30c; 80c for 3.

Crimson Rambler-Deep crimson. A beautiful climbing rose. Foliage rich, dark green; rapid grower. You all know this rambler and why not have plenty for your trellises, garden wall and home?

Price, each, $35 \mathrm{c} ; 95 \mathrm{c}$ for 3.

Paul's Scarlet Climber-Vivid scarlet. Unusually large flowers for a climber. You're sure to be delighted with this wonderful rambler. Brilliant semi-double flower's in clusters of color. They hold their bright color for two to four weeks. Cut thenl liberally - the bush will not be injured.

Price, each, 35e; 95e for 3.

Galdenia-lellow to cream. One of the best yellow elimbers. Bud comes as bright yellow, opening to cream-double bloom. I'rice, each, 50e; \$1.35 for 3 .

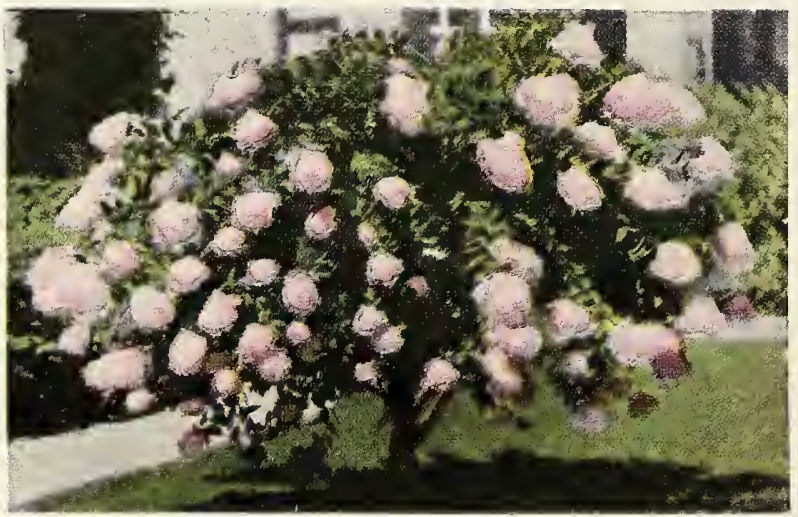

\section{Bush Roses}

Baldwin's Selected Varieties, Page 32

\section{Hydrangea P.G.}

This showy shrub is perfectly hardy. Its large clusters of pure white blossoms, later turning to soft pink, bloom from August until late fall. Superb either in single or group plantings; often used as a hedge. A beautiful shrub both for its blooms and its rich green foliage - and should be used much more than it is. Grows 4 to 5 feet high.

Price, 1 1/2 to $2 \mathrm{ft}$, each, 35c; $\$ 2.00$ for 6 . 


\section{Sour Cherries}

Montmoreney-50e each: $\$ 4.55$ for 10 ; \$4.5.00 10r 100.

Garly 12 iolnuond-150 eateh; $\$ 4.25$ for I0; $\$ 10.00$ for 100.

(A11 5 to $6 \mathrm{ft}$. 9/16 in. caliper trees)

bonturency-Sonr-Ripens 1 a $t e$ in June and is best sour cherry for the marliet. Malies delicious pies; fine for canning. Fruit larger th a n Richmond; bright red, acid flavor.

Big growers who know tell us: "There is good money-big money, to be male in scowing Hontmorency for the canning fantory market." And they are planting henvily now.

Garly Riehmond-Somr-One of the most popular sour cherries, unexcelled for cooking. Darli red, tart and juicy. Hardy trees uninjured by cold. Big crops.

Sweet Clierries, Page 24

\section{The Famous Montmorency}

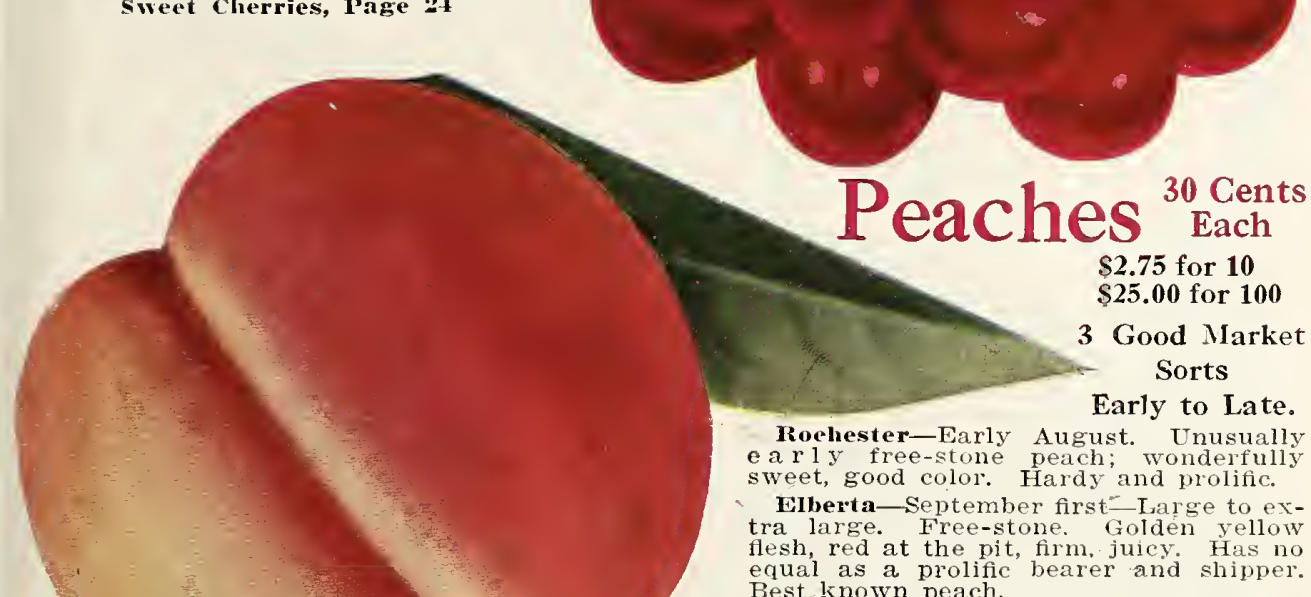
Best known peach.

Gold Drop-Late September. Excellent late, well linown peach much in demand. Good annual crops of firm juicy, yellow, medium sized fruits.

Elberta

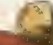

(other Varieties, page $\ddot{\geq}$

\section{Apples 35 Cents Apples Each}

(Other, Varieties, Pages 21-22)

RED DELICIOUS

Known the World Over

Winter. Brilliant dark red, shading to yellow at blossom end. Large to very large; white, tender juicy flesh. Wonderfully rich sub-acid flavor-truly delicious. Ships without bruising; makes a wonderful appearance, commanding top prices. Comes into bearing early. 
